\title{
The aquatic systems of Doñana (SW Spain): watersheds and frontiers
}

\author{
L. Serranoํ, M. Reina, G. Martín, I. Reyes, A. Arechederra, D. León \& J. Toja \\ Dep. Plant Biology and Ecology. University of Sevilla. P.O. Box. 1095, Sevilla 41080. \\ ${ }^{1}$ corresponding author: serrano@us.es
}

\begin{abstract}
Doñana includes an extraordinary variety of aquatic systems. They are broadly classified according to their location (on either aeolian sands or marshland) as their hydrology largely depends on the geomorphology of their basins. Their chemical composition is mainly influenced by rainfall, evaporative concentration, groundwater discharge, biogeochemical interactions at the sediment-water interface, and the quality composition of their watersheds. The influence of the watershed can be studied at different scales of observation. Rainfall infiltration in sandy soils is usually high so surface runoff becomes a rare event of very short duration during floods which, nonetheless, exerts a huge influence on the limnology of temporary ponds on aeolian sands. The water quality of the Doñana marshland, on the contrary, is influenced by long-term processes taking place on large-scale areas: sediment deposition, eutrophication and heavy metal pollution. The review of the main literature on the limnology of the Doñana aquatic systems during the past two decades, enable us to make a comparison in time focusing on the interactions at the frontier between terrestrial and aquatic systems within watersheds. Presently, the eastern area of the Doñana marshland is particularly affected by the low quality of the incoming flowing water compared with the more isolated southern marshes within the National Park. Water from the lower strech of the Guadiamar River ("Entremuros"), that floods the marshes of "Lucio El Cangrejo Grande", showed a significant correlation between inorganic suspended solids and total $\mathrm{P}(\mathrm{r}=0.807, \mathrm{p}<0.05)$ during 2003-04, indicating an important contribution of inorganic particulates to the eutrophication of this area. The northern streams of the "Arroyo del Partido" watershed have not significantly improved their water quality in the last two decades despite the construction of two waste-water treatment plants, being total $\mathrm{P}$ correlated to dissolved phosphate concentration $(\mathrm{r}=0.995, \mathrm{p}<0.01)$ during 2003-05. A general increase in $\mathrm{NO}_{3}{ }^{-}$concentrations have been detected in all studied aquatic systems of the Doñana marshland, including those with the highest water quality ("Arroyo de la Rocina") during the last two decades. Despite wetland management requires a watershed approach, successive hydrologic projects in Doñana have failed to address the great spatio-temporal variability of processes affecting water quality in this area.
\end{abstract}

Keywords: temporary ponds, marshland, streams, water quality, long-term study, eutrophication.

\section{RESUMEN}

Doñana alberga una extraordinaria variedad de sistemas acuáticos que se clasifican de forma general según su localización, bien en las arenas o en la marisma, ya que su hidrología depende, fundamentalmente, de la geomorfología de sus cuencas. La composición química de sus aguas varía en función de la lluvia, la evaporación, la descarga freática, las interacciones biogeoquímicas en la interfase agua-sedimento y el estado ecológico de sus cuencas. La influencia de la cuenca se puede estudiar a escalas distintas. La lluvia se infiltra fácilmente en la arena por lo que la escorrentía se convierte en un episodio raro y breve que, sin embargo, afecta considerablemente al funcionamiento limnológico de las lagunas temporales sobre arenas. Por el contrario, la calidad del agua en la marisma de Doñana está afectada por procesos extensos y largos, como la sedimentación, la eutrofización y la contaminación por metales pesados. Una revisión de la bibliografía limnológica permite realizar un estudio comparativo de las últimas dos décadas, centrado en las interacciones que tienen lugar en las fronteras entre los ecosistemas terrestres y acuáticos que comparten las cuencas de estos cuerpos de agua. Actualmente, la zona Este de la marisma está especialmente afectada por la baja calidad de las aguas de entrada en comparación con la zona Sur del Parque Nacional que se encuentra más alejada de estos aportes. El agua que discurre por el último tramo del encauzamiento del rio Guadiamar ("Entremuros") inunda las marismas cercanas ("Lucio El Cangrejo Grande") y mostró una correlación significativa entre la carga de materia inorgánica en suspensión y la concentración de P total $(r=0.807, p<0.05)$ durante el periodo 2003-04, indicando la importante contribución del material particulado inorgánico en la eutrofización de esta zona. En la zona Norte, la calidad del agua en los arroyos de la cuenca del Partido no ha mejorado significativamente en la últimas dos décadas, a pesar de la construcción y funcionamiento de dos estaciones depuradoras de aguas residuales. Las concentraciones de $P$ total y fosfato disuelto en el agua se encontraron altamente correlacionadas $(r=0.995, p<0.01)$ durante el periodo 2003-05. En las dos últimas décadas, se ha detectado un incremento de la concentración de $\mathrm{NO}_{3}{ }^{-}$en los siste- 
mas acuáticos estudiados en la marisma, incluído áquel con la mejor calidad del agua ("Arroyo de la Rocina"). A pesar de que nadie duda que la gestión de los humedales require una estrategia a nivel de cuenca hidrográfica, los sucesivos proyectos hidrológicos que se desarrollan en Doñana no llegan a abarcar la gran escala espacio-temporal de los procesos que afectan a la calidad de su aguas.

Palabras clave: lagunas temporales, marisma, arroyos, calidad del agua, eutrofización.

\section{INTRODUCTION}

Doñana is considered the most relevant wetland area in Spain. Despite its significance for wildfowl, research into the limnological processes of this vast wetland area started merely two decades ago. Prior to this, there were some scattered information published by re-known specialists in aquatic invertebrates that visited the area following the tradition of naturalists "exploring" Doñana in the previous $19^{\text {th }}$ century and providing new zoological and botanical cites to the region. This was the case of surveys for the collection of rotifers (De Ridder, 1962), crustaceans (Dussart, 1962, 1967, Estrada, 1973, Armengol, 1976) aquatic insects (Bigot \& Marazanof, 1965, Marazanof, 1967) and phytoplankton (Margalef, 1976). Later, microinvertebrates continued to be studied in the ponds, particularly ciliates (PérezCabrera \& Toja, 1989), rotifers (Mazuelos et al., 1993) and crustaceans (Galindo et al., 1994 a,b, Ruiz et al., 1996, Serrano \& Toja 1998, Fahd et al., 2000, Serrano \& Fahd, 2005). The study of macroinvertebrates was mainly focused on Odonata, Heteroptera and Coleoptera from the marshes (Montes, 1980, Montes \& RamírezDíaz, 1982), and later resumed with the impact of the red swamp crayfish (Gutierrez-Yurrita et al., 1998, Alcorlo et al., 2004). An extensive survey of aquatic and semiaquatic Coleoptera has been recently performed (Millán et al. 2005). Aquatic vertebrates such as amphibians have been extensively studied by Díaz-Paniagua (1979, 1988, 1990, Díaz-Paniagua et al., in press) while fish have received some attention much later (Fernández-Delgado et al., 2000). The study of aquatic vegetation in Doñana started also with early "explorations" to be later focused on particular aspects (García-Murillo et al., this issue). A floristic revision of aquatic macrophytes is provided by García-Murillo et al. (1993) and Espinar
(2000). Aquatic vegetation has also been studied with a limnological perspective (Bernués, 1990, Duarte et al., 1990, Sousa \& García-Murillo, 1999; Espinar et al., 2002), being the work by Espinar (2004) the most extensive study on the ecology and distribution of aquatic macrophytes in the Doñana marshland.

The water composition of the Doñana marshland and the quality of the surface waters entering the marshes were thoroughly studied during the 80 's and reviewed by Arambarri et al. (1996). The first ecological studies (aimed at relating biological populations to environmental variables) were performed by Furest \& Toja (1981) and Montes et al. (1982). Later, the Doñana ponds were typified according to their hydrology and chemical composition (GarcíaNovo et al., 1991; Manzano, 2001), their hydrology and substrate (Bravo \& Montes, 1993) or their hydro-chemistry and littoral vegetation (Muñoz-Reinoso, 1996). The larger size of Santa Olalla and Dulce ponds made them suitable for many limnological studies (López et al., 1991, Toja et al., 1991, Sacks et al., 1992, Serrano et al., 1994, 1999, Toja et al., 1997, López-Archilla et al., 2004) compared to the rest of ponds (Bernués 1990, López et al., 1994, Serrano \& Toja, 1995). Additionally, the relevance of sediment in the functioning of these shallow aquatic systems has been brought forward in numerous publications (Grimalt et al., 1991, Jaúregui \& Toja, 1993, López et al., 1997, Díaz-Espejo et al., 1999, Álvarez et al., 2001, Serrano et al., 2003). The interaction with their surrounding terrestrial ecosystems has also been studied under different perspectives, such as vegetation-groundwater interactions (García-Novo et al., 1996, Zunzunegui et al., 1998), climate change (Sousa \& GarcíaMurillo, 2003) and landscape management (Muñoz-Reinoso \& García-Novo, 2005). 


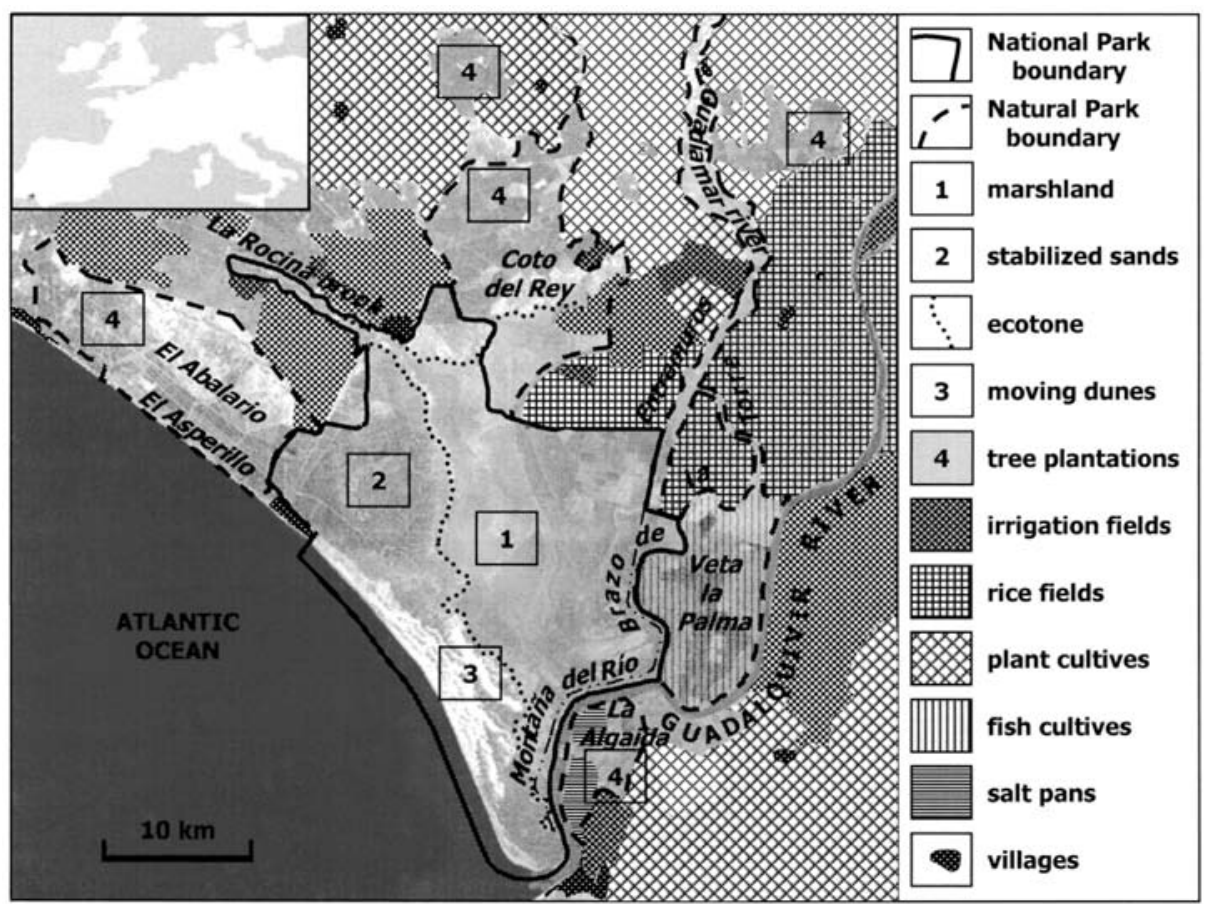

Figure 1. Location of Doñana featuring different landscapes: marshland (1), stabilized sands (2), moving dunes (3), and the ecotone between aeolian sands and marshes. Antropic activities have deeply modified the landscape into: pine/gum-trees plantations (4), irrigation fields, rice fields, dry-land plant cultivars, artificial wetlands for fish cultives, salt pans, and villages. Localización del área de Doñana y sus diferentes tipos de paisaje: marisma (1), arenas estabilizadas (2), arenas móviles (3) y ecotono entre el manto arrasado y la marisma. Se incluyen paisajes muy antropizados como plantaciones de pino/eucalipto (4), regadios, arrozales, cultivos de secano, piscicultura extensiva, salinas y núcleos urbanos.

This wealth of limnological information enable us to make a comparison of the main aquatic systems of Doñana. We will focus on processes affecting water quality that take place at the frontier between terrestrial and aquatic ecosystems at different spatio-temporal scales.

\section{STUDY AREA}

The Doñana region $\left(37^{\circ} \mathrm{N}, 6^{\circ} \mathrm{W}\right)$, extends along the coastal plain of the Gulf of Cádiz from the left bank of the estuary of the Guadalquivir river to the estuary of the Tinto river, and inland from the lower Guadalquivir River valley to the uplands of "El Aljarafe" (Sevilla) and "Condado de Niebla" (Huelva). It includes several territories with a different degree of environmental protection covering over 100000 ha: a Biological Reserve created in 1964, a National Park (designated as a Ramsar site in 1982 and a
World Heritage Site by UNESCO in 1995) and a Natural Park created as a surrounding protective area in 1989 (Fig. 1). At the same time, the Doñana region constitutes a space featuring the widest variety of pressures regarding the use and assignment of water resources. In 1990, Doñana entered onto the Montreaux Record of Ramsar sites under threat because a number of disturbances related to the conservation of the marshes had the potential to change its ecological character. The Doñana region hosts a population of nearly 180000 inhabitants whose activities are devoted to agriculture and tourism. Rice fields occupy a vast extension on the east margin (about $35000 \mathrm{ha}$ ). Water for the growth of rice is mainly provided by the Guadalquivir River, while 15000 ha of irrigation fields, scattered over the sandy soils on the west and northern areas, are watered by the aquifer which produces a groundwater withdrawal of 55-60 $\mathrm{hm}^{3}$ per year (Cruz Villalón, 2005). 
Additionally, two large tourist resorts lie bordering the coast ("Matalascañas") and the marshes ("E1 Rocío"). The former concentrates over 63000 people in summer, while the latter attracts over half a million people during a traditional pilgrimage held in spring.

Doñana has a Mediterranean climate with Atlantic influence, generally classified as dry subhumid. Rainfall is quite variable, both within a year and over the years, with a $580 \mathrm{~mm}$ yearly average, about $80 \%$ of which is distributed throughout a wet period from the end of September to the beginning of April. Summers are very dry and hot, while winters are short and mild. Water balance is generally deficient as rainfall exceeds evapotranspiration only during 3-4 months of the year (Siljeström \& Clemente, 1990). Potential evapotranspiration is very high with a yearly average of about $900 \mathrm{~mm}$ (Ménanteau, 1982). The deviation of rainfall to the yearly average (CDYP) showed an irregular sequence of hydrologic cycles $\left(1^{\text {st }}\right.$ October- $30^{\text {th }}$ September) during the past 16 years: 6 wet, 5 dry and 5 moderate cycles (Fig. 2).
Doñana started to be formed in the Quaternary age when the estuary of the Guadalquivir River was enlarged and reshaped by the formation of sandy spits after the last postglacial transgression. The alluvial deposition of fine materials brought about the filling of the former estuary and progressively isolated it from the sea. In 1984, the construction of a levee on the right bank of the Guadalquivir River ("Montaña del Río", Fig. 1) minimized the tidal influence on the marshland which eventually became a continental formation (Clemente et al., 2004). Consequently, the deposits on this ancient plain present a rather heterogeneous lithology as it is partially covered by aeolian sands, while the central plain presents a saline silty-clay layer of up to $100 \mathrm{~m}$ thickness with deltaic deposits of sand and gravel increasing towards the north. The permeability of the main geomorphological units is very different: the aeolian sands correspond to an unconfined aquifer (with a shallow watertable and several flow systems) while groundwater is confined below the silty-clay deposits of the floodplain. Both units composed

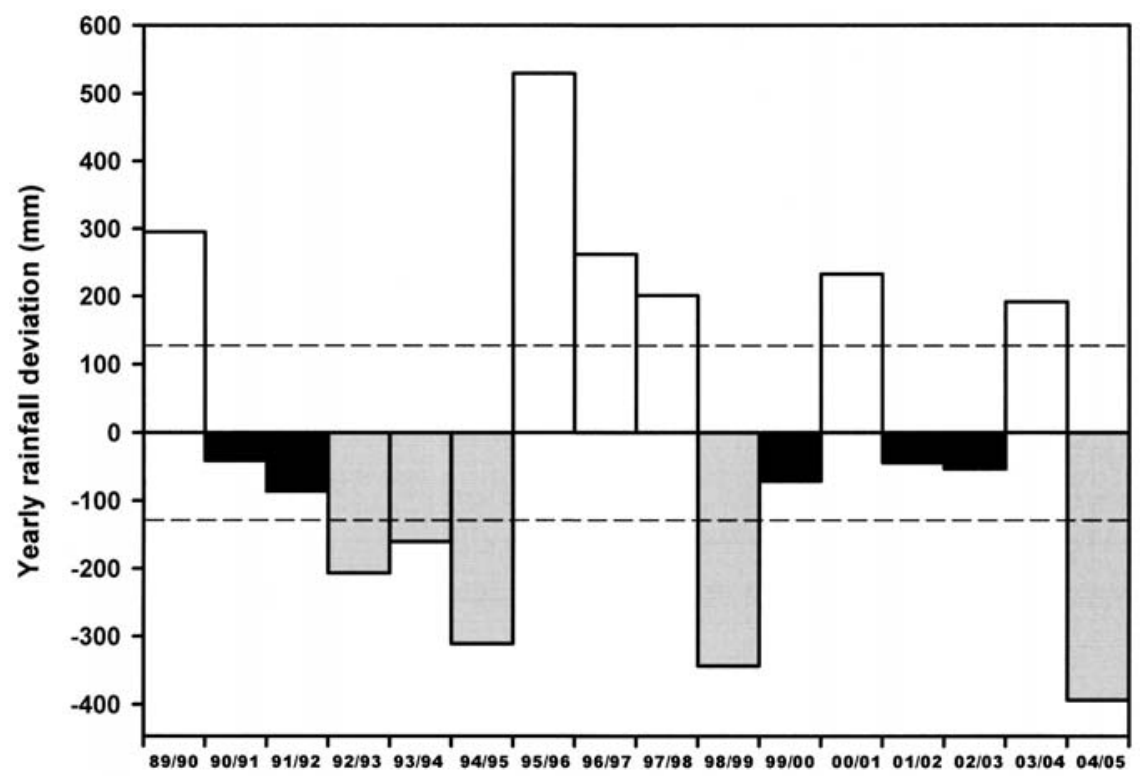

Figure 2. Deviation coefficient of rainfall to a yearly average (CDYP) of $563.2 \mathrm{~mm}$ recorded in the past 16 hydrologic cycles $(1989 / 90-2004 / 05)$. Confidence limits at $95 \%$ of significance $( \pm 128 \mathrm{~mm})$ are indicated by dotted lines. Each hydrologic cycle was classified as wet $(\mathrm{CDYP}>128 \mathrm{~mm})$, dry $(\mathrm{CDYP}>-128 \mathrm{~mm})$ or moderate $(128 \mathrm{~mm}>\mathrm{CDYP}<-128 \mathrm{~mm})$. Coeficiente de desviación a la media anual de lluvia (CDYP) de $563.2 \mathrm{~mm}$ durante los últimos 16 ciclos hidrológicos (1989/90-2004/05). Los límites del intervalo de confianza al $95 \%$ de significación $( \pm 128 \mathrm{~mm})$ se indican con líneas punteadas. Cada ciclo hidrológico se ha clasificado como húmedo (CDYP> $128 \mathrm{~mm})$, seco (CDYP> $-128 \mathrm{~mm}$ ) o moderado $(128 \mathrm{~mm}>C D Y P<-128 \mathrm{~mm})$. 
an aquifer system of about $3400 \mathrm{~km}^{2}$ bottomed by impermeable marine marls known as the "Almonte-Marismas" aquifer (Llamas, 1990). The depth of the aeolian sand deposits varies from over $100 \mathrm{~m}$ on the coast to barely $10 \mathrm{~m}$ at the northern edge of the Park. Groundwater recharge is produced by rainfall infiltration in the unconfined aquifer at an estimated rate of $200 \mathrm{~mm} \mathrm{y}^{-1}$ (Vela, 1984). Groundwater in the confined aquifer, however, flows at a rate of 0.1 $1 \mathrm{~cm} \mathrm{y} \mathrm{y}^{-1}$ (Konikow \& Rodríguez-Arévalo, 1993). The silty floodplain and the sand mantle also create two contrasting landscapes which make contact with each other along an ecotone locally known as "La Vera-Retuerta" (Fig. 1).

The aquatic ecosystems of Doñana are broadly classified according to their location (on either aeolian sands or marshland) as their hydrology largely depends on the geomorphology on their basins. Outside the protected areas, watersheds are severely altered by human activities (Fig. 1). The lower valley of the Guadalquivir River is devoted to agriculture (traditional cultivars of olive trees, irrigated crops, and rice fields) and farming of cattle and horses. The watershed of the Guadiamar River extends to the highlands on the north (Sierra de Aracena) where soils are partially covered by scrub vegetation and plantations of gum-trees. Downstream, the river receives the drainage and seepage of the spoil heaps from an open-cast polymetallic sulphide mine (Aznalcóllar) through one of its tributaries (Arambarri et al., 1996). The dumping of $5 \mathrm{hm}^{3}$ of mud and acid water with high concentrations of heavy metals in the mining accident of April 1998 flooded an extension of 2600 ha downstream. An extensive cleaning activity took place in the river floodplain and the riverbanks were later protected as a buffer area ("Corredor Verde del Guadiamar"). The lower stretch of the Guadiamar River runs between two levees ("Entremuros") built in 1956. Its final stretch is canalised and connected to a dead arm-river ("Brazo de la Torre") that drains to the estuary of the Guadalquivir River (Fig. 1).

The flatness of the vast floodplain occupied by the marshland (about $23000 \mathrm{ha}$ ) is altered at a topographic scale of a few $\mathrm{cm}$ that creates depressions (locally known as "lucios") and upper areas ("paciles") which have the appearance of emerged islands ("vetas") during heavy floods. On the north-western area, surface water to this plain is supplied by rainfall and the overflood of small water flows ("Arroyos de La Rocina, del Partido, Cañada Marín and Cañada Mayor") which drain southwards into the Park through a channel called "Caño de la Madre de las Marismas del Rocío". On the north-eastern marshland, the Guadiamar River used to drain southwards through numerous small creeks (or "caños"), but most of its water-flow is presently deviated to the estuary of the Guadalquivir river so only a minor part of it reaches the marshes through both pipes ("Caño del Guadiamar") and a complex channel network ("Entremuros-Brazo de la Torre") which also carries the drainage of the nearby rice-fields. Quantitavely less important, but ecologically relevant, is the ground water seepage along the ecotone ("La Vera") that provides humidity to grass meadows and hygrophitic vegetation ("algaidas"), and feed small creeks ("caños" and "sotos") especially during heavy rainy periods. In some spots of the marshland, groundwater seepage maintains permanent sub-surface springs ("ojos").

The Doñana marshland is flooded seasonally by freshwater, depending on hydro-meteorological conditions, as the Guadalquivir River is the only permanent river in the area and its tidal influence is currently minimal. This marked seasonality of flooding periods followed by summer drought has accentuated the endorreic character of the marshland (Clemente et al., 2004). The resulting ionic composition of the "lucios" is dominated by $\mathrm{Cl}^{-}$ and $\mathrm{Na}^{+}$as a result of the solubilization of salts from the sediment, the concentration of salts being dependent on the frequency and duration of flooding in each area (Clemente et al., 1998). Currently operative salt pans are located on the left bank of the Guadalquivir river. On the southeastern boundary of the Natural Park, 37 artificial wetlands (total surface about 3000 ha) are devoted to extensive fish cultures ("Veta La Palma"). Tidal marshes, in contrast, have been reduced to a narrow fringe along the banks of the Guadalquivir River (Gallego \& García-Novo 2003). 


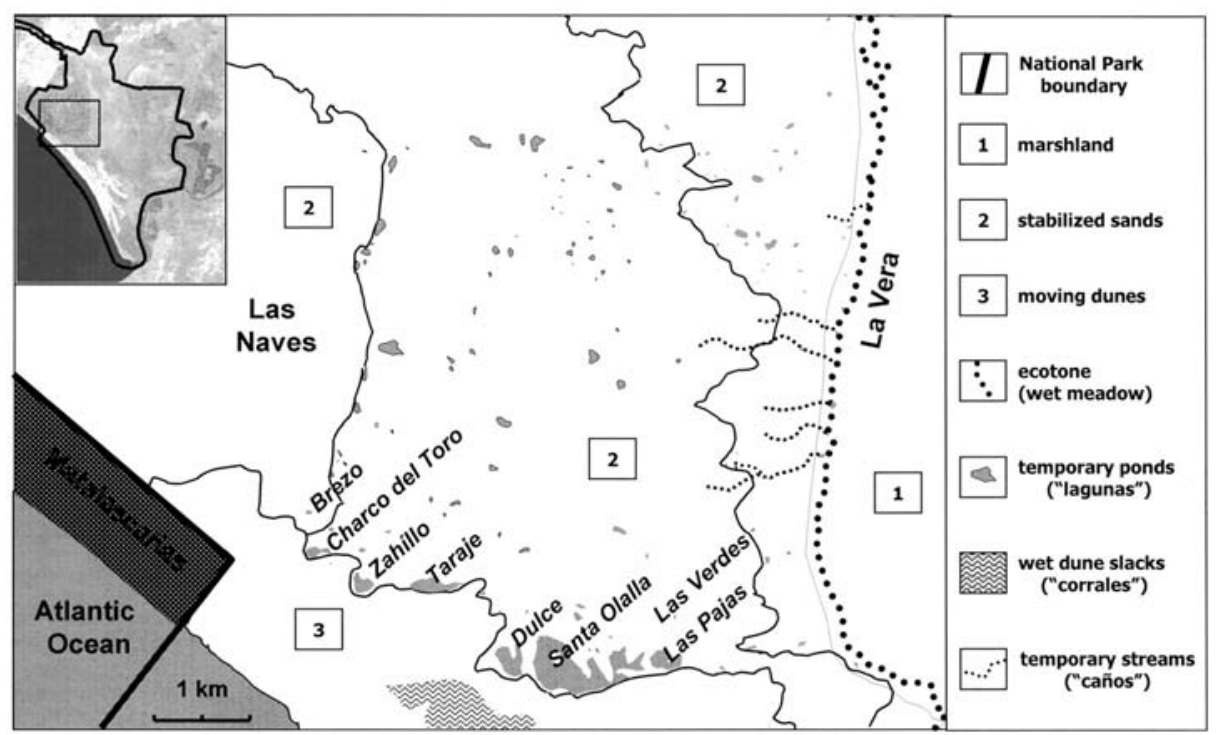

Figure 3. Location of a variety of aquatic systems on aeolian sands within the Doñana Biological Reserve (wet meadows, temporary ponds, wet dune slacks and temporary streams). The names of the main "peridune ponds" fringing the moving dunes are indicated. Localización de diversos sistemas acuáticos sobre el manto arrasado en la Reserva Biológica de Doñana (pastizales de la Vera, lagunas temporales, corrales encharcados y caños). Se indican los nombres de las principales lagunas peridunares situadas a lo largo del frente de dunas móviles.

The Holocene aeolian sand mantle is composed of several dune generations originally deposited by marine drift (Vanney \& Menanteau, 1985). A system of moving dunes with several dune fronts runs parallel to the coast-line with a NW-SE direction (max. altitude: $30 \mathrm{~m}$ ). Within the Doñana Biological Reserve, the sand mantle is mostly covered by Mediterranean scrub (stabilized dunes) with a species composition closely following water availability which, in turn, depends on groundwater flow systems of different spatial scales (Muñoz-Reinoso \& García-Novo, 2005). In this undulating landscape, hundreds of small ponds appear when the water table rises above the topographical surface during heavy rains (Fig. 3). These ponds (locally known as "lagunas") are fed by freshwater (rainfall, runoff and groundwater discharge) and have no surface or groundwater connection to the sea so they cannot be properly called lagoons though they receive salts of marine origin through airborne deposition. Their groundwater feeding is relatively complex due to changes in recharge and topographic boundaries that modify their connection to different aquifer flow systems over time (Sacks et al., 1992, Muñoz-Reinoso, 2001). They range widely in size (from rain puddles to shallow lakes) and in flooding duration (from days to decades), but they all have been reported to dry out eventually. Hence, they all are temporary water bodies exhibiting wide fluctuations of water level. Many attempts have been made to classify them into different categories (permanent, semipermanent, seasonal, ephemeral), but a short number of observations have produced contradictory results (García-Novo et al., 1991, Bravo \& Montes, 1993, Manzano, 2001). As a whole, the Doñana ponds form a system of temporary water bodies of remarkable singularity in Europe with a high protection status (Serrano \& Toja, 1995, Williams et al., 2001). The area protected within the Biological Reserve (Fig. 3) covers a groundwater discharge surface of about $200 \mathrm{~km}^{2}$ (Allier et al., 1974). The density of ponds in this area during winter floods is 6 ponds per 100 ha (holding water for 1-6 months) and 1 pond in 100 ha (holding water for more than 6 months, García-Novo et al., 1996). A few artificial wetlands are maintained by groundwater pumping, while digging water-holes in the ground near ponds ("zacallones") for cattle drinking during dry periods is a very common practice. 
Aquatic systems on aeolian sands within the Doñana Natural Park are also interesting and heterogenous (Fig. 1). A cliff formed by fossils dunes ("Médano del Asperillo") runs along the coast to the west of the National Park and reaches a maximum altitude of $100 \mathrm{~m}$. Rainfall and groundwater seepage drain to the sea through small ravines crossing the cliffs, providing shelter to some hygrophytic species (Díaz-Barradas \& MuñozReinoso, 1992). Ponds also appeared inland to this formation, scattered over an area covering about 25000 ha called "El Abalario" (Sousa \& García-Murilllo, 1999). Vestiges of Atlantic peatbogs can be found there and along the margins of La Rocina brook. The extensive plantations of pines and gum-trees ("Coto del Rey") shelter numerous small ponds during floods. A total of 568 temporary wetlands on sandy soils have been recorded by the local administration in the Doñana region (Junta de Andalucía, 2002). The only permanent aquatic system over sands (the lagoon of Tarelo) fringes the pine plantation of "La Algaida" on the left bank of the Guadalquivir River. Its basin was artificially excavated for sand and gravel extraction, and it is fed by rainfall and groundwater seepage from the estuary of the Guadalquivir River (Serrano et al., 2004).

\section{MATERIAL AND METHODS}

Rainfall data was obtained from the meteorological station of "Palacio de Doñana" (RBD-
CSIC). New physico-chemical data presented here corresponded to four different locations. The experiment with limnocorrals was carried out in several temporary ponds (Doñana Biological Reserve): at November-December 1991 (Jabata pond) and November 1995 (Las Verdes and Dulce ponds). Groundwater samples were collected from shallow piezometers following the methodology used by López et al. (1994). Limnocorrals (1 m diameter, $1 \mathrm{~m}$ height) and runoff samplers (5 1 volume) were made of translucient impervious plastic as described in Serrano et al. (1999).

Samplings of the floodplain and water-flows entering the marsh area of "Lucio El Cangrejo Grande" (Doñana Natural Park) were carried out bimonthly from February 2003 to September 2004. Three sampling stations were located in the central floodplain of this area; one sampling station in the Guadiamar River at "Vuelta de la Arena" ("Entremuros"), 3 sampling stations along its canal ("Canal de Aguas Mínimas") and one sampling station at the rice field main outlet ("Canal Principal de Desagüe"). In May 2004, five sites within the lower Guadiamar River watershed were sampled, both in the upper stretch of "Entremuros" and in several tributaries: "Arroyo de la Cigüeña", "Arroyo de Gato", "Arroyo Chucena" and "Arroyo Algarbe". Samplings of the Rocina-Partido watershed were performed in November 2003, December 2004, March and June 2005. The Rocina brook was sampled in its main stream just before

Table 1. Chemical composition of water inside limnocorrals (rainfall + groundwater discharge), outside them (rainfall + groundwater discharge + runoff), in surface runoff and phreatic water below several ponds at the onset of their filling period. Composición quimica del agua dentro de los limnocrrales (lluvia + descarga subterránea) y fuera de ellos (lluvia + descarga subterránea + escorrentía), de la escorrentía superficial y el agua freática en algunas lagunas al comienzo de su llenado.

\begin{tabular}{|c|c|c|c|c|c|c|c|c|c|}
\hline & \multicolumn{3}{|c|}{ La Jabata pond } & \multicolumn{3}{|c|}{ Las Verdes pond } & \multicolumn{3}{|c|}{ La Dulce pond } \\
\hline & \multirow{2}{*}{$\begin{array}{l}(7 / 11 / 91) \\
\text { phreatic }\end{array}$} & \multicolumn{2}{|c|}{$(5 / 12 / 91)$} & \multicolumn{3}{|c|}{$(12 / 11 / 95)$} & \multicolumn{3}{|c|}{$(12 / 11 / 95)$} \\
\hline & & inside & outside & phreatic & outside & runoff & inside & outside & runoff \\
\hline E.C. $\left(\mathrm{mS} \mathrm{cm}^{-1}\right)$ & 0.81 & 0.87 & 0.41 & 0.74 & 2.70 & 1.86 & 12.5 & 5.41 & 0.88 \\
\hline $\mathrm{pH}$ & 7.0 & 6.4 & 7.3 & 8.2 & 7.2 & 6.3 & 7.3 & 7.5 & 7.1 \\
\hline Alkalinity (meq $1^{-1}$ ) & 0.7 & 0.6 & 0.2 & 1.3 & 0.6 & 0.2 & 2.5 & 0.8 & 0.6 \\
\hline $\mathrm{i}-\mathrm{P}\left(\mu \mathrm{g}^{-1}\right)$ & 111 & 9 & 9 & 37 & 251 & 115 & 208 & 242 & 533 \\
\hline $\mathrm{N}^{-} \mathrm{NO}_{3}^{-}\left(\mu \mathrm{g} \mathrm{l}^{-1}\right)$ & 1.4 & 15.4 & 14.0 & 0.5 & 12.1 & 3.9 & 150.6 & 156.4 & 13.6 \\
\hline $\mathrm{N}-\mathrm{NO}_{2}^{-}\left(\mu \mathrm{g} \mathrm{l}^{-1}\right)$ & 1.9 & 2.4 & 1.5 & 7.3 & 642.6 & 24.9 & - & - & - \\
\hline $\mathrm{NH}_{4}^{+}\left(\mathrm{mg} \mathrm{l}^{-1}\right)$ & 0.96 & 0.28 & 0.45 & 0.20 & 0.45 & 0.41 & 0.08 & 0.80 & 1.13 \\
\hline
\end{tabular}


draining to the marsh. The Partido stream was sampled across the "Raya Real", at its delta, and in a tributary ("Caño Marín").

Conductivity (compensated with temperature at $20{ }^{\circ} \mathrm{C}$ ) and $\mathrm{pH}$ were recorded in situ. Water samples (1-2 1) were collected, stored at $4{ }^{\circ} \mathrm{C}$ and filtered in the laboratory through Whatman GF/C filters within the next $24 \mathrm{~h}$. Suspended solids were analyzed gravimetrically, in 3-4 replicates, using previous dry filters $\left(100^{\circ} \mathrm{C}\right)$. The concentration of inorganic suspended solids was estimated after ignition $\left(450^{\circ} \mathrm{C}, 4 \mathrm{~h}\right)$. The rest of analyses were carried out in duplicates. COD determinations were performed using $\mathrm{KMnO}_{4}$ as oxidative agent. Total alkalinity was determined by titration (Rodier, 1981). The concentration of i-P was determined following the method of Murphy \& Riley (1962). Tot-P was analyzed as i-P after acid digestion of the unfiltered water sample with $0.5 \mathrm{M} \mathrm{H}_{2} \mathrm{SO}_{4}$ and $\mathrm{K}_{2} \mathrm{~S}_{2} \mathrm{O}_{8}(0.5-1 \mathrm{~g})$ at $120{ }^{\circ} \mathrm{C}$ for $4 \mathrm{~h}$ (De Groot \& Golterman, 1990). The concentration of $\mathrm{NO}_{2}^{-}$and $\mathrm{NH}_{4}{ }^{+}$were determined by colorimetry (Rodier, 1981). The concentration of $\mathrm{NO}_{3}{ }^{-}$was measured as $\mathrm{NH}_{4}{ }^{+}$after complete oxidation with $\mathrm{TiCl}_{3}$ (Golterman, 1991).

\section{RESULTS AND DISCUSSION}

The chemical composition of the Doñana aquatic systems is mainly influenced by rainfall, evaporative concentration, groundwater discharge, biogeochemical interactions at the sedimentwater interface, and the quality composition of their watersheds. The influence of the watershed can be studied at different scales of observation. Rainfall usually infiltrates easily through sandy soils so surface runoff rarely reaches the ponds (only for very short time-lapses during heavy rainfall). The water quality of the Doñana marshland, on the contrary, is influenced by long-term processes taking place on large-scale areas (such as sediment deposition, eutrophication and heavy metal pollution).

The chemical composition of the unconfined aquifer is considered rather uniform, dominated by $\mathrm{Ca}\left(\mathrm{HCO}_{3}\right)_{2}$ and with a salinity usually lower than $500 \mu \mathrm{g} \mathrm{l}^{-1}$, except at discharge areas becau- se of the influence of biochemical processes (Llamas, 1990). As a whole, the aquifer shows a vertical gradient in salinity, from brine-water near the land surface to freshwater at $80 \mathrm{~m}$ of depth (Konikow \& Rodríguez-Arévalo, 1993). Below the confined aquifer, salinity increases in a NE-SW direction pushing the interphase between the aquifer recharge and the fossil marine groundwater to the NE boundary of the Park where extensive irrigation fields happen to be developing (Plata \& Ruiz, 2003).

The high proportion of $\mathrm{NaCl}$ in rainwater due to marine influence affects the composition of shallow groundwater, but the high ratio of $\mathrm{Mg}^{2+}$ over $\mathrm{Na}^{+}$suggests that wet and dry atmospheric deposition has not yet been properly addressed (Lozano, 2004). The successive cycles of flooding and evaporation in the discharge areas have enriched in $\mathrm{NaCl}$ the shallow free groundwater (or phreatic) below the pond basins as it was shown by López et al. (1994) in water samples collected in piezometers $(<2 \mathrm{~m}$ depth) during a dry hydrologic year. $\mathrm{Ca}^{2+}$ dominated over $\mathrm{Na}^{+}$only in a small depression within the dune tail where recharge dominated over discharge flow and water was temporary deposited. Conductivity and total alkalinity of groundwater below the ponds showed little relationship to morphometry or trophic state, suggesting the existence of local flow systems.

Limnocorral experiments were used in the temporary ponds to isolated both surface and groundwater sources at the onset of their filling period. The chemical composition of water inside the limnocorral (rainfall+groundwater discharge) and outside it (rainfall+groundwater discharge+runoff) was compared to the phreatic water below the ponds and to surface runoff collected in the watershed (Table 1). The chemical composition of the water filling the ponds resulted from an interaction of both surface and groundwater sources during discharge, but general trends were difficult to predict. Firstly because water budgets have not yet been elucidated with sufficient resolution and, secondly because of the impact of sparse local events on these shallow systems. For example, heavy rainstorms $(>80 \mathrm{~mm})$ that only represented $1.4 \%$ of total 
observations in a 7-year record (Serrano et al., 1999) can disrupt the pond development and revert it to earlier successional stages (Toja et al., 1991). De Castro-Ochoa \& Muñoz-Reinoso (1997) elaborated a multiple regression model for water-table fluctuations of the dune wetslacks that depended on rainfall, time lapse between two consecutive measurements and present depth. They found, however, that groundwater discharge at the ponds did not fit into their dune aquifer model because pond feeding did not only depend on rainfall. A hydrologic budget for the largest pond during the rainy season (OctoberMarch) estimated that surface sources (rainfall and runoff) accounted for $48 \%$ of the water input during very dry years $(<250 \mathrm{~mm}$ of annual rainfall), but reached $100 \%$ during extremely wet cycles ( $>1000 \mathrm{~mm}$ of annual rainfall). The rest of the water input was due to groundwater discharge, from both a shallow phreatic and a deep water table (Sacks 1989).

A review of studies on the ionic composition in the Doñana aquatic systems reveals the influence of the different scales of observation in each study. The hydroperiod (or duration of water on the surface) and the water origin are relevant hidrologic features that influence the ionic composition of water, but their assesment is greatly affected by the duration of the study period. The first extensive survey (47 ponds) of water chemical composition was performed by García-Novo et al. (1991) during the heavy floods of winter 1990. Again, $\mathrm{Na}^{+}$and $\mathrm{Cl}^{-}$were the dominant ions in all pond waters. The ratio of $\mathrm{Ca}^{2+}$ over $\mathrm{Na}^{+}$was not a good predictor compared to the $\mathrm{Mg}^{2+} / \mathrm{Na}^{+}$ratio, probably due to the local effect of microtopography and vegetation on $\mathrm{CaCO}_{3}$ precipitation. A ratio of $\mathrm{Mg}^{2+}$ over $\mathrm{Na}^{+}$higher than 0.25 (in meq/l) corresponded to discharge areas, and a lower ratio indicated recharge areas where water runoff could be temporary deposited due to the presence of a high concentration of organic matter and/or clay in the sediment. They segregated the ponds in three discharge groups according to their location, mineralization and trophic state (Fig. 3): 1) ponds in "Las Naves", 2) those along the ecotone between the moving dunes and the stabilized
Table 2. Maximum and minimum values of water conductivity $\left(20^{\circ} \mathrm{C}\right)$ recorded in the water surface of the most visited ponds from $1989 / 90$ onwards, indicating wet $\left({ }^{\mathrm{W}}\right)$, dry $\left({ }^{\mathrm{d}}\right)$ and moderate cycles $\left({ }^{\mathrm{m}}\right)$. Valores máximos y mínimos de la conductividad $\left(20^{\circ} \mathrm{C}\right)$ registrados en la superficie del agua de las lagunas más visitadas desde 1989/90, indicando los ciclos húmedos ( $(w)$, secos (d) y moderados ( $m$ ).

\begin{tabular}{|c|c|c|c|c|c|c|}
\hline \multirow{2}{*}{$\begin{array}{l}\text { Hydrologic } \\
\text { cycle }\end{array}$} & \multicolumn{2}{|c|}{ Santa Olalla } & \multicolumn{2}{|c|}{ Dulce } & \multicolumn{2}{|c|}{ Taraje } \\
\hline & Max & Min & $\operatorname{Max}$ & Min & Max & Min \\
\hline $1989 / 90^{w}$ & 4.1 & 0.4 & 5.8 & 0.2 & 7.4 & 0.1 \\
\hline $1990 / 91 \mathrm{~m}$ & 4.3 & 1.3 & 7.1 & 0.8 & 10.6 & 1.6 \\
\hline $1991 / 92 \mathrm{~m}$ & 16.5 & 2.3 & 12.5 & 1.0 & 22.0 & 4.1 \\
\hline $1992 / 93 \mathrm{~d}$ & 28.4 & 4.4 & 10.6 & 1.2 & 15.4 & 6.9 \\
\hline $1993 / 94^{d}$ & - & 6.0 & 2.0 & 1.7 & 13.3 & 1.2 \\
\hline $1994 / 95^{d}$ & - & - & - & - & - & - \\
\hline $1995 / 96^{w}$ & 1.1 & 0.7 & 5.9 & 0.5 & 1.8 & 0.3 \\
\hline $1996 / 97$ w & 0.7 & 0.3 & 0.6 & 0.3 & 2.3 & 0.4 \\
\hline $1997 / 98 \mathrm{w}$ & 0.6 & 0.4 & 0.5 & 0.4 & 8.5 & 0.5 \\
\hline $1998 / 99 \mathrm{~d}$ & $11.6^{*}$ & $1.7^{*}$ & $16.6^{*}$ & $1.6^{*}$ & 11.1 & 6.1 \\
\hline $1999 / 00 \mathrm{~m}$ & $9.2 *$ & $1.9^{*}$ & $3.5^{*}$ & $1.0^{*}$ & 5.6 & 1.5 \\
\hline $2000 / 01 \mathrm{w}$ & $5.7 *$ & $1.7 *$ & $2.5^{*}$ & $0.6^{*}$ & 3.4 & 0.9 \\
\hline $2001 / 02 \mathrm{~m}$ & - & - & - & - & - & - \\
\hline $2002 / 03 \mathrm{~m}$ & 8.3 & 2.3 & 3.7 & 0.8 & 2.7 & 1.7 \\
\hline $2003 / 04$ w & 7.7 & 1.1 & 3.3 & 0.4 & 4.4 & 0.4 \\
\hline $2004 / 05^{d}$ & 19.3 & 1.9 & 1.9 & 1.0 & 14.9 & 8.6 \\
\hline
\end{tabular}

* LÓPEZ-ARCHILA et al. (2004)

sands ("peridune pond" system), and 3) those between the stabilized sands and the marshland ("La Vera"). Later, Muñoz-Reinoso (1996) enlarged this classification to 5 groups by including the wet-slack formation of the moving dunes, and dividing the "peridune ponds" in two other groups according to pond size.

Water $\mathrm{pH}$ is usually alkaline in the discharge areas, while acidic water $(\mathrm{pH} 4-5)$ has been occasionally reported when rainfall is temporary deposited on rich organic soils. The combination of alkaline waters over siliceous sand basins makes these water bodies rather singular compared to other European wetlands (Serrano \& Toja, 1995).

Hydrochemical classifications of ponds based on absolute limits have, so far, proved evasive as the ionic composition of the Doñana ponds change widely in time (Serrano \& Toja, 1995). Table 2 shows the change in water conductivity recorded in some of the most visited ponds during the last two decades. In Taraje pond, conductivity ranged from 0.1 to $8.5 \mathrm{mS} \mathrm{cm}^{-1}$ during wet years, and from 1.2 to $22.0 \mathrm{mS} \mathrm{cm}^{-1}$ 
during dry years. Low maximum conductivity values corresponded to wet cycles while high minimum values to dry years in all ponds, but the relationship between conductivity and rainfall was not linear because conductivity also reflected the past conditions of previous dry cycles: the minimum conductivity values were not attained in 1995/96 despite it was the wettest cycle in the record $(1093 \mathrm{~mm})$ as it had been preceeded by several dry years.

The conductivity range was widest in the larger pond (Santa Olalla: from 0.3 to $28.4 \mathrm{mS}$ $\left.\mathrm{cm}^{-1}\right)$. Its larger watershed ensured a higher contribution of rainfall and the flooding of a considerable extension of soil and vegetation which accounted for the solubilization and leaching of salts which progresively concentrated in the water as evaporation proceeded. Sacks (1989) proved that the higher mineralization of Santa Olalla pond was also achieved by the downgradient movement of solutes through seepage from its neighbouring ponds (Dulce and Las Pajas) due to its larger evaporative discharge and lower altitude. She estimated that the residence time for $\mathrm{Cl}^{-}$was 6 years in Dulce pond and 34 years in Santa Olalla pond. During extremely wet periods, this pond complex (Santa Olalla-DulceLas Pajas) behaves as a flow-through floodplain of about 100 ha (García-Novo et al., 1991) that evacuates water and solutes to the nearby marshes through intermittent creeks.

Flooding and runoff also contribute to the loading of nutrients and dissolved organic compounds to the ponds. The concentration of i-P in surface runoff water was relatively high compared to groundwater discharge (Table 1), but these differences were brief: ten days were enough to equilibrate a six-fold difference between the i-P concentrations inside and outside a limnocorral in Las Verdes pond during the filling period of 1991 (Serrano \& Toja, 1995). A careful study of the P-fractional sediment composition showed that the incoming i-P was partially adsorbed by the sediment during the first weeks of the filling period. A pond with a sustrate rich in $\mathrm{Fe}$ $\left(>10 \mathrm{mg} \mathrm{g}^{-1} \mathrm{dw}\right.$ ) significantly increased its pool of inorganic P-bound to $\mathrm{Fe}$, while another rich in organic matter $(>17 \%)$ increased its fraction of
org-P solubilised by EDTA (Díaz-Espejo et al., 1999). Serrano et al. (1999) showed that the Doñana ponds received i-P from their watershed during heavy rainstorms after drought. In Dulce pond, i-P concentration was 100 times higher in the littoral than in the open-water area. Soil samples from the sandy uplands and the floodplain meadow, fresh scrub (Halimium halimifolium), and cattle manure leached i-P concentrations higher than $0.9 \mathrm{mg} \mathrm{g}^{-1} \mathrm{dw}$ in distilled-water under laboratory conditions, suggesting that this material was a source of $\mathrm{P}$ to runoff water draining to the pond shore. The slow decomposition rate of litter in arid sandy soils of Doñana can explain the accumulation of nutrients in the upland areas of the pond watersheds where leaching of soluble compounds from litter can last up to 4 moths after deposition (Gallardo \& Merino, 1993). The accumulation of organic matter, in turn, accounts for the dominance of organic P-fractions in the pond sediment (Serrano et al., 2003). The contribution of terrigenous lipids to the sedimentary composition (Grimalt et al., 1991) and the detection of organic P-compounds derived from vegetation in the sediment such as phytate (Serrano et al., 2000a) proved the strong influence of the watershed on these aquatic systems.

Rainfall itself accounted for the leaching from fresh vegetation of soluble polyphenols (Serrano, 1992). During floods, dissolved organic matter is washed from the fringing vegetation and carried by runoff water to the ponds where the concentration of DOC can reach up to $120 \mathrm{mg} \mathrm{l}^{-1}$ during heavy rainfall (Serrano, 1994). Although the input of DOC by rainfall and runoff water is a common process in all aquatic systems: e.g. $10-25 \%$ of total yearly input in Canadian lakes (Schindler 1992), the singularity of this process here relies on the unpredictability of the flooding events in the Mediterranean climate. Consequently, the Doñana ponds exhibit very contrasting conditions in different years that led Allier et al. (1974) to state that they had distrophic phases during floods. During distrophic phases, pond water shows a very dark colour due to high concentrations of DOM. Flooding itself produces the dilution of solutes and particulates, bringing about a drastic reduction of the phyto- 
plankton populations and disrupting their previous succesional development (Toja et al., 1991). No direct effect of polyphenols on primary production has been proved in the ponds (Serrano et al., 1993) despite these compounds are able to chelate micronutrients (Serrano \& Guisande, 1990). Vertical attenuation coefficients of PAR in the water of a pond rich in dissolved polypehnols were similar to those of the hypereutrophic Santa Olalla pond where chlorophyll $a$ concentrations reached upt to $2 \mathrm{mg} \mathrm{l}^{-1}$ (Serrano et al., 1994). Flooding is, therefore, the cause of both the phytoplankton dilution and the polypehnolic enrichment. The perturbation caused by flooding in the ponds is so extreme that it resembles the flood pulse of tropical floodplains, in which heavy floods can clean water bodies and rearrange the communities to earlier successional stages (Junk \& Weber, 1996). The drainage and vegetation pattern in the watershed determines the extent and variability of the runoff input to each pond during floods (García-Novo et al., 1996). Xerophytic scrub (Halimium halimifolium) growing in the upland areas of the pond watershed leached a higher amount of polypehnols than bulrushes from the floodplain under artificial rainfall experiments (Serrano, 1992). The fate of the dissolved polyphenols was also different in each pond till they dissapeared on the dry sediment (Serrano, 1994). Dissolved polyphenols are easily degraded by sunlight so photo-oxidation can account for their disappearance in the water. The depth of the water column limits the amount of sunlight that can penetrate in each pond and thus the extent of the photo-degradation of polyphenols in each pond (Serrano et al., 2000b).

The expected development of the Doñana ponds during a moderate hydrologic cycle would be a low concentration of polypehnols in the water which, in combination with a moderate water depth, would allow the growth of extensive macrophyte beds. Biomass of submersed vegetation have been reported to reach up to $450 \mathrm{~g} \mathrm{dw}$ $\mathrm{m}^{-2}$ in Dulce pond (López et al., 1991). As the ponds dry out, organic matter is partially mineralised on the dry sediment (Serrano, 1992). Hence, the concentration of sediment organic

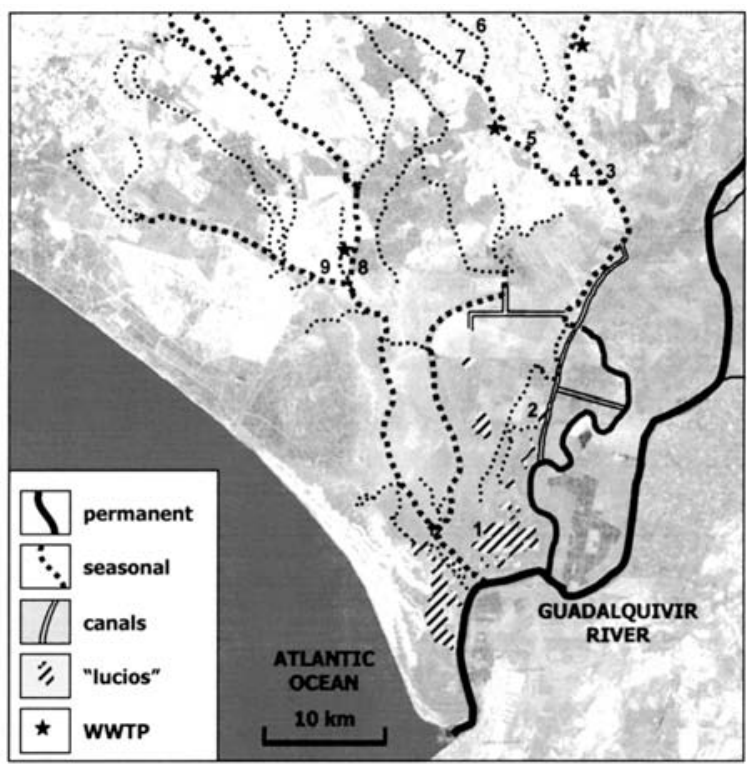

Figure 4. Map of the surface watersheds in the Doñana region. The Guadalquivir River is the only permanent river. Other water-flows are intermittent under the tidal influence of the former or by the effect of urban sewage effluent. The rest of water-flows are considered seasonal. Some artificial canals are distinguished. Location of presently working waste-water treatment plants (WWTP) is indicated. Sampling sites in the watershed: "Lucio de los Ánsares" (1), "Lucio Cangrejo Grande" (2), "Guadiamar-Entremuros" (3), "La Cigüeña" (4), "Gato" (5), "Chucena" (6), "Algarbe" (7), El Partido stream (8), La Rocina brook (9). Mapa de la cuenca superficial de drenaje en el área de Doñana. El río Guadalquivir es el único curso de agua permanente. Otros rios y arroyos son intermitentes bajo la influencia mareal de aquel o debido al efluente de las depuradoras. El resto de los cursos de agua se consideran estacionales. Se distinguen algunos canales artificiales. Se indica la localización de las plantas depuradoras de residuos urbanos (WWTP) operativas. Los puntos muestreados en la cuenca fueron: Lucio de los Ánsares (1), Lucio Cangrejo Grande (2), Guadiamar-Entremuros (3), arroyo de la Cigüeña (4), arroyo del Gato (5), arroyo de Chucena (6), arroyo Algarbe (7), arroyo del Partido (8), arroyo de La Rocina (9).

matter is inversely correlated to the duration of flooding (Jaúregui \& Toja, 1993). During dry periods, the vegetation pattern surrounding the ponds changes rapidly: hygrophytic species showed regression while xerophytic species advanced to lower areas (Zunzunegui et al., 1998). A flooding period following a long drought, therefore, will produce a larger impact of the watershed on the pond water composition regarding nutrient and dissolved organic matter concentrations. The variability of the hydro-me- 
teorological conditions in the area ensures the unpredictability of this terrestrial-aquatic frontier. Furthermore, vegetation changes induced by antropic disturbance in relation to groundwater abstraction add more uncertainty to this interaction (Muñoz-Reinoso, 2001).

Long-term and large-scale processes have also been reported to alter the water composition of water bodies on aeolian sands. The alluvial aquifer of the Guadalquivir River has long been exposed to a severe $\mathrm{NO}_{3}{ }^{-}$pollution due to the excessive use of fertilizers in its cacthment. About $8 \mathrm{mM}$ of $\mathrm{NO}_{3}{ }^{-}$were already reported in the estuary in 1987 (I.T.G.E., 1993). Groundwater pollution was most likely the cause of the high concentrations of $\mathrm{NO}_{3}^{-}$(up to $1.5 \mathrm{mM}$ ) found in the water of Tarelo lagoon fed by groundwater seepage from the estuary of the Guadalquivir River (Serrano et al., 2004). The study of both ecological and historical records showed that the vegetation of Doñana has been deeply affected by management practices since the first quarter of the $17^{\text {th }}$ century (GranadosCorona et al., 1998). Deep sediment cores from Dulce and Santa Olalla ponds showed that Tot-P concentrations had increased exponentially since 1960's suggesting that recent changes in land management have contributed to their eutrophication (López et al., 1993). A decrease in the availabity of water may also have contributed to a decrease of their water quality. In a climatic context, Sousa \& García-Murillo (2003) sugges- ted that Doñana is under an overall tendency of dessication due to an increase in aridity initiated at the end of the $19^{\text {th }}$ century. More recently, the groundwater pumping for urban water supply to the tourist resort of Matalascañas has been reported to damage nearby ponds (Brezo and Charco del Toro, Fig. 3) located at less than $1 \mathrm{~km}$ to the pumping area during the drought period of 1992-94 (Serrano \& Serrano, 1996).

The Doñana marshland is basically fed by direct rainfall on its floodplain and by several watersheds: Guadiamar River $\left(1180 \mathrm{~km}^{2}\right)$, the Partido stream $\left(300 \mathrm{~km}^{2}\right)$ and La Rocina brook (about $1000 \mathrm{~km}^{2}$ ). Secondarily, it is fed by groundwater discharge along the ecotone and through seepage streams ("sotos"). Lastly, the tidal influence from the estuary of the Guadalquivir River is minimal nowadays. The relative contribution of each water source is expected to vary according to dry, moderate and wet cycles. On average, the water flow from the Guadiamar River is 3-7 times larger than the rest of sources, but since its drainage was modified by channels and levees in 1956, most of its water drains directly to the estuary of the Guadalquivir River (Espinar, 2004). At present, only several depressions located on the eastern and southern areas of the National Park are flooded by the Guadiamar River through a network of pipes and pumping stations. Nine outlets along the levee ("Montaña del Río"), eight of them provided with floodgates, maintain the confinement

Table 3. Range values and means (or mean and standard deviation) of water conductivity $\left(20^{\circ} \mathrm{C}\right), \mathrm{pH}$, nutrient concentrations and suspended solids (s.s.) in two marsh sites at different sampling periods. Intervalo máx-min y valores medios (o media y desviación estándar) de la conductividad $\left(20^{\circ} \mathrm{C}\right), \mathrm{pH}$, concentración de nutrientes y sólidos en suspensión (s.s.) en dos zonas de muestreo de la marisma durante periodos distintos de estudio.

\begin{tabular}{|c|c|c|c|c|c|c|c|c|c|c|c|}
\hline & \multicolumn{6}{|c|}{ 1981-82* } & \multirow{2}{*}{\multicolumn{2}{|c|}{$\frac{1997 * *}{\text { Lucio Ánsares }}$}} & \multirow{2}{*}{\multicolumn{3}{|c|}{$\frac{2002-04 * * *}{\text { Lucio Cangrejo }}$}} \\
\hline & \multicolumn{3}{|c|}{ Lucio Ánsares } & \multicolumn{3}{|c|}{ Lucio Cangrejo } & & & & & \\
\hline & $\max$ & $\min$ & mean & $\max$ & $\min$ & mean & mean & SD & $\max$ & $\min$ & mean \\
\hline E.C. $\left(\mathrm{mS} \mathrm{cm}^{-1}\right)$ & 35.7 & 7.9 & 21.4 & 36.7 & 20.2 & 31.2 & 4.25 & 0.37 & 8.0 & 1.6 & 4.4 \\
\hline $\mathrm{pH}$ & 10.2 & 6.9 & 8.6 & 9.2 & 6.9 & 7.9 & 9.3 & 0.42 & 8.5 & 7.8 & 8.1 \\
\hline $\mathrm{N}-\mathrm{NO}_{3}^{-}\left(\mathrm{mg} \mathrm{l}^{-1}\right)$ & 6.2 & 1.3 & 3.8 & 10.8 & 3.2 & 5 & 0.2 & 0.03 & 4.7 & 0.1 & 1.2 \\
\hline $\mathrm{i}-\mathrm{P}\left(\mu \mathrm{g} \mathrm{l}^{-1}\right)$ & 620 & 33 & 195 & 587.4 & 78.3 & 228.4 & 8 & 3 & 39 & 0 & 13 \\
\hline Tot-P $\left(\mu \mathrm{g} \mathrm{l}^{-1}\right)$ & - & - & - & - & - & - & - & - & 974.7 & 45.5 & 179.6 \\
\hline s.s. $\left(\mathrm{mg} \mathrm{l}^{-1}\right)$ & 628 & 19 & 186 & 124 & 18 & 50 & - & - & 433 & 33 & 102 \\
\hline
\end{tabular}


Table 4. Concentrations of dissolved nutrients and COD at several sites within the lower Guadiamar river watershed. Concentración de nutrientes y DQO en varios puntos de la cuenca baja del río Guadiamar.

\begin{tabular}{lcrrrr}
\hline & Entremuros & Cigüeña & Gato & Chucena & Algarbe \\
\hline $\mathrm{N}-\mathrm{NO}_{3}^{-}\left(\mathrm{mg} \mathrm{l}^{-1}\right)$ & 0.33 & 0.46 & 0.57 & 0.46 & 0.46 \\
$\mathrm{~N}_{2} \mathrm{NO}_{2}^{-}\left(\mathrm{mg} \mathrm{l}^{-1}\right)$ & 0.10 & 0.21 & 0.22 & 0.47 & 0.04 \\
$\mathrm{~N}^{-} \mathrm{NH}_{4}^{+}\left(\mathrm{mg} \mathrm{l}^{-1}\right)$ & 0.02 & 0.02 & 0.02 & 0.03 & 0.02 \\
$\mathrm{i}-\mathrm{P}\left(\mathrm{mg} \mathrm{l}^{-1}\right)$ & 0.26 & 0.25 & 0.22 & 0.11 & 0.02 \\
$\mathrm{COD}\left(\mathrm{mg} \mathrm{l}^{-1}\right)$ & 11.36 & 12.48 & 15.60 & 14.88 & 14.56 \\
\hline
\end{tabular}

of the water outflow during winter and spring though, occasionally, the levee is overflowed at heavy floods. During moderate and dry cycles, freshwater is accumulated in the depressions ("lucios") causing the solubilization of salts from the top sediment. As the confined water evaporates, their salts and particulates become increasingly concentrated. The resulting ionic composition of the "lucios" is dominated by $\mathrm{Cl}^{-}$ and $\mathrm{Na}^{+}$, the concentration of salts being dependent on the frequency and duration of flooding in each area (Clemente et al., 1998). One of the eight projects planned for the hydrologic regeneration of the marshland ("Doñana 2005") plans to eliminate part of this levee in order to increase the connection between the southern marsh and the estuary of the Guadalquivir River.

The water quality of the waters entering the Doñana marshland has been extensively studied in the past decades, while the water composition within the "lucios" is scarcer. Table 3 shows a comparison in time of the water composition at two sites (Fig. 4): "Lucio de los Ánsares" between 1981-82 (I.N.I.A., 1984) and 1995-97 (Espinar, 2004), and "Lucio Cangrejo Grande" between 1981-82 (I.N.I.A., 1984) and 2002-2004 (present data). Despite the recent data was recorded during a much wetter period, the physicochemical changes recorded in these "lucios" were mainly due to major hydrologic changes that took place in the past. The levee that isolated the marshland from the estuary of the Guadalquivir River ("Montaña del Río") was built in 1984 and enlarged in 1998. Before its construction, the southern marshland received a large tidal influence that was reflected in both the large conductivity of the water and the high concentration of nutrients in the sampling of 1981-82.

The hydrology of the "Lucio Cangrejo Grande" had already been altered in 1956 with the construction of two levees that directed the water flow of the Guadiamar River to the estuary through a channel connected to a dead arm-river ("Brazo de la Torre"). The 8-fold difference in the average water conductivity after two decades was most likely due to a dilution of the tide water. At the end of September, rice pads located on the east, are drained through an outlet which is connected to the canal feeding the study area. The salinity of the water drained by this outlet is relatively low because rice require less than $1 \mathrm{~g}^{-1}$ for growth. As this freshwater outlet was not operative till 1988, the study area received the direct influence of the estuarine water which presented an average water conductivity of $33.3 \mathrm{mS} / \mathrm{cm}$ at the mouth of the estuary during the sampling of 1981-82. The evaporation of water in the rice pads during the growth season increased the water conductivity of the outlet only slightly $\left(2 \mathrm{mS} \mathrm{cm}^{-1}\right)$ due to the recirculation of water through the rice fields. Therefore, the freshwater output of nearby rice pads contributed to reduce the salinity of the estuarine water during high tide. Although the concentration of i-P was lower in the recent sampling, the high concentration of suspended matter produced a high concentration of Tot-P as both variables were strongly correlated $(\mathrm{r}=0.978, \mathrm{p}<0.01)$. The concentration of $\mathrm{NO}_{3}{ }^{-}$did not change considerably after two decades, suggesting that this area has received a high nutrient load for a long time. Furthermore, the nutrient concentrations of several tributaries to the Guadiamar River during a wet period in the spring of 2004 (Table 4) was similar to that found by previous authors more than two decades ago (Cabrera et al., 1984). Additionally, the Guadiamar River has created a chronic pollution of heavy metals in the area due to both resuspension of sediments from the river bed during floods (Cabrera et al., 1984, Arambarri et al., 1996) and direct overflow of the mine dam. Such overflow was recorded during the winter floods of 1989 (Dolz \& Velasco, 1990). This 
Table 5. List of main studies on water quality of Doñana marshland (before the mining spill of Aznalcóllar in 1998), indicating type of pollutant, location and reference. Lista de los principales estudios sobre la calidad del agua en la marisma de Doñana (antes del desastre minero de Aznalcóllar in 1998), indicando tipo de contaminante, localización y referencia.

\begin{tabular}{|c|c|c|}
\hline pollutant & location & Reference \\
\hline \multirow{4}{*}{ Olive-mill effluents } & Guadiamar-Entremuros & Cabrera et al., 1984; 1986 \\
\hline & & Albaigés et al. 1987 \\
\hline & Guadalquivir estuary & Cabrera et al., 1986 \\
\hline & marshes & Arambarri et al., 1984; 1996 \\
\hline Petroleum hydrocarbons & Guadiamar-Entremuros & Albaigés et al., 1987 \\
\hline \multirow[t]{5}{*}{ Organochlorine plaguicides } & Guadiamar-Entremuros & Albaigés et al., 1987 \\
\hline & marshes & Albaigés et al., 1987 \\
\hline & Guadiamar-Entremuros & Cabrera et al., 1984; 1987 \\
\hline & & González et al., 1987 \\
\hline & & Ramos et al., 1994 \\
\hline \multirow[t]{6}{*}{ Heavy metals } & & Arambarri et al., 1996 \\
\hline & Guadalquivir estuary & Zurera et al., 1987 \\
\hline & marshes & Cabrera et al., 1987 \\
\hline & & Arambarri et al., 1984;1996 \\
\hline & & Albaigés et al., 1987 \\
\hline & & Ramos et al., 1994 \\
\hline \multirow[t]{4}{*}{ Fertilizers } & Guadiamar-Entremuros & González et al., 1987 \\
\hline & & Arambarri et al., 1996 \\
\hline & El Partido stream & González et al., 1987 \\
\hline & & Arambarri et al., 1996 \\
\hline \multirow{3}{*}{ Particulate organic matter } & Guadiamar-Entremuros & González et al., 1987 \\
\hline & El Partido stream & González et al., 1987 \\
\hline & & Arambarri et al., 1996 \\
\hline
\end{tabular}

chronic pollution probably accounted for the finding of a 3-times higher heavy metal concentration in seston of reference sites from Doñana compared to unpolluted sites reported in the literature during the monitoring of the Aznalcóllar mining spill (Prat et al., 1999).

Unfortunately, the quality of the waters entering the Doñana marshland has imporved little over the past decades regarding the concentration of dissolved nutrients despite olive mill effluents have been significantly reduced and several waste-water treatment plants have been developed (in both cities and rural areas). The variety of pollutants detected in the surface water-flows of the Doñana watershed reflects a large concern on this issue (Table 5). The evaluation made by Arambarri et al. (1996) over the 1980's decade concluded that the waters of the Partido stream ought to be treated as they contained high concentrations of organic matter and nutrients that were hazardous to other aquatic ecosystems (other streams and the freshwater marsh of "La Madre de las Marismas del Rocío"). The Rocina brook, in contrast, rated the highest water quality, while the estuary of the Guadalquvir showed an aceptable water quality except for its high salinity.

Another report on the quality of water-flows entering the Doñana National Park estimated that the Partido stream carried a yearly nutrient load of $62.4 \mathrm{Tm}$ of organic matter (COD), 2.7 Tm of P and 6.4 of N (Toja et al., 1992). More than a decade later and two waste-water treatment plants later (located in Almonte and El Rocío villages), the Partido stream is still highly polluted compared to the Rocina brook which does not receive urban waste-water (Table 6). Nevertheless, there has been a considerable increase of $\mathrm{NO}_{3}{ }^{-}$concentration in both water-flows during the past decade probably due to an increase in cultivated land and fertilizer applications. The influence of this pollution on the eutrophication of the nearby marshes should not be overlooked. During dry periods, 
such as the spring of 2005, the effluents from the waste-water treatment plants of El Rocío and Almonte villages run downstream into the National Park through the "Madre de las Marismas del Rocío" creek.

Besides the impact of waste-water treatment plants on river water quality, which is by itself an issue of great concern causing a severe disturbance at a regional scale (Martí et al., 2004), the Doñana marshland also features a large sedimentation rate which is contributing to its eutrophication. The concentration of suspended solids has increased in many areas during the past decades (Tables 3 and 6). In the lower strecht of the Guadiamar River ("Entremuros"), the waterflows feeding the nearby marshes ("Lucio de El Cangrejo Grande") showed a significant correlation between inorganic suspended solids and Tot-P $(\mathrm{r}=0.807, \mathrm{p}<0.05)$ during 2003-04. Most of the suspended matter was inorganic (60$93 \%$ ) containing $\mathrm{CaCO}_{3}$ particles adsorbed to $\mathrm{P}$ in the form of hydroxi-apatite. Previous works have reported that soil particles are eroded and resuspended from the Guadiamar River watershed during floods, bringing about an increase of nutrient concentrations in the downstream waters (González Quesada et al., 1987, Arambarri et al., 1996). Even in the absence of floods, the higher speed of the water current through artificial canals promote the erosion of its bed and margins increasing the concentration of suspended solids in the water (Mintegui, 1999). In constrast, Tot-P concentration in the Partido watershed was not significantly correlated to suspended solids but to i-P concentration $(\mathrm{r}=0.995, \mathrm{p}<0.01)$, indicating the sewage origin of its water. This area has received great attention because of the huge scale of its riverbank erosion during floods. Since 1995, a sediment load of nearly $3 \times 10^{6} \mathrm{~m}^{3}$ has been deposited in the marshes (Mintegui 2005). Both processes of eutrophication and sediment deposition have run parallel to the expansion of emergent macrophytes in the Doñana marshland, bringing about a drastic reduction of its open-water areas since 1956 (Espinar, 2004). At the same time, the recent expansion of introduced species, such as Azolla filiculoides, in the Doñana marshes could be a consequence of eutrophication as this $\mathrm{N}_{2}$ fixing symbiont thrives when the $\mathrm{N} / \mathrm{P}$ ratio is unbalanced in the ecosystem.

A proper wetland management requires a watershed approach. At the same time, the quality of the waters draining through a watershed will reflect the quality of the corresponding terrestrial ecosystems (Margalef 1983). In the Doñana region, groundwater recharge takes place by rain infiltration on the aeolian

Table 6. Mean and range values of water conductivity $\left(20^{\circ} \mathrm{C}\right)$, concentration of nutrients, suspended solids (s.s.), and COD within the watersheds of El Partido stream and La Rocina brook during two sampling periods. Valores medios e ntervalo máx-min de la conductividad $\left(20{ }^{\circ} \mathrm{C}\right.$ ), concentración de nutrientes, sólidos en suspensión (s.s.) y DQO en la cuenca de los arroyos del Partido y La Rocina durante dos periodos distintos de muestreo.

\begin{tabular}{|c|c|c|c|c|c|c|c|c|c|c|c|c|}
\hline & \multicolumn{6}{|c|}{ 1991-92* } & \multicolumn{6}{|c|}{ 2003-04 } \\
\hline & \multicolumn{3}{|c|}{ El Partido } & \multicolumn{3}{|c|}{ La Rocina } & \multicolumn{3}{|c|}{ El Partido } & \multicolumn{3}{|c|}{ La Rocina } \\
\hline & $\max$ & $\min$ & mean & $\max$ & $\min$ & mean & $\max$ & $\min$ & mean & $\max$ & $\min$ & mean \\
\hline E.C. $\left(\mathrm{mS} \mathrm{cm}^{-1}\right)$ & 1.42 & 0.53 & 1.13 & 0.63 & 0.21 & 0.39 & 1.29 & 0.44 & 0.97 & 0.57 & 0.41 & 0.49 \\
\hline $\mathrm{N}-\mathrm{NH}_{4}{ }^{+}\left(\mathrm{mg} \mathrm{l}^{-1}\right)$ & 27.4 & 3.6 & 9.9 & 1.4 & 0.2 & 0.5 & 15.0 & 0.3 & 8.6 & 7.5 & 0.5 & 2.9 \\
\hline $\mathrm{N}-\mathrm{NO}_{2}^{-}\left(\mathrm{mg} \mathrm{l}^{-1}\right)$ & 0.04 & $<0.01$ & 0.02 & 0.03 & $<0.01$ & 0.01 & 0.28 & 0.14 & 0.19 & 0.02 & $<0.01$ & 0.015 \\
\hline $\mathrm{N}-\mathrm{NO}_{3}^{-}\left(\mathrm{mg} \mathrm{l}^{-1}\right)$ & 0.14 & 0.02 & 0.08 & 0.89 & 0.10 & 0.38 & 11.45 & $<0.01$ & 7.57 & 1.26 & 0.01 & 0.67 \\
\hline $\mathrm{i}-\mathrm{P}\left(\mathrm{mg} \mathrm{l}^{-1}\right)$ & 3.2 & 0.2 & 1.3 & 0.13 & 0 & 0.04 & 3.4 & 0.4 & 1.7 & 0.08 & 0.03 & 0.005 \\
\hline Tot-P $\left(\mathrm{mg} \mathrm{l}^{-1}\right)$ & 5.4 & 0.3 & 2.8 & 0.8 & 0.1 & 0.3 & 4.2 & 1.1 & 2.7 & 2.0 & 0.4 & 1.2 \\
\hline s.s. $\left(\mathrm{mg} \mathrm{l}^{-1}\right)$ & 103 & 33 & 67 & 175 & 22 & 97 & 311 & 12 & 161 & 92 & 32 & 62 \\
\hline $\operatorname{COD}\left(\mathrm{mg} \mathrm{l}^{-1}\right)$ & 90.4 & 19.3 & 61.4 & 50.3 & 21 & 31.8 & - & - & - & - & - & - \\
\hline
\end{tabular}

*TOJA et al. (1992) 
sands covering about $3400 \mathrm{~km}^{2}$. The Doñana marshland covers a vast extension of both deeply transformed areas (dessicated marsh, rice fields, irrigation fields) and less transformed marshes (National and Natural Parks) which are hydrologicaly connected to each other. The surface watershed draining to the marshland extends by narrow corridors to the pyritic deposits of the northern uplands, while the lower valley of the Guadalquivir River is the recipient of waters draining through a huge watershed of more than $57500 \mathrm{~km}^{2}$. Both surface and groundwater resources ought to be extremely difficult to manage at this massive scale and so, successive hydrologic projects carried out in Doñana have failed in many aspects. The recently developed hydrologic regeneration plan for Doñana (Doñana 2005) will bring a better connectivity to the Guadalquivir River, but rice fields continue to be segregated in this estrategy despite they are not isolated from the Doñana aquatic systems, neither by water surface nor by aerial depositions. The outlet water from rice-pads is flooding the nearby marshes (on the eastern margin of both the Natural and the National Park) every year at the end of the rice growing-season. Instead of lamenting on the issue, rice fields could become a source of freshwater in the hydrologic budget of the nearby marshes which, in turn, will create more concern on the control and monitoring of fertilizers and pesticides in the area.

\section{ACKNOWLEDGEMENTS}

We are grateful to all the people that have participated in our limnology group during the past decades: A. Furest, T. López, C. Guisande, N. Gabellone, M. A. Casco, J. Prenda, J. C. Muñoz, J. Jaúregui, N. Mazuelos, J. A. García-Sánchez, M. D. Galindo, F. García-Bouzas, A. DíazEspejo, J. L. Moreiras, I. Calzada-Bujak, K. Fahd, M. D. Burgos, A. Plazuelos and E. Alcalá. Recent data corresponded to research projects supported by "Consejería de Medio Ambiente, Junta de Andalucía" and the Ministry of Envrionment (Doñana 2005).

\section{REFERENCES}

ALBAigÉS, J., J. ALGABA, P. ARAMBARRI, F. CABRERA, G. BALUJA, L. M. HERNÁNDEZ \& J. CASTROVIEJO. 1987. Budget of organic and inorganic pollutants in the Doñana National Park (Spain). Sci. Total Environ., 63: 12-28.

ALCORLO, P., W. GEIGER \& M. OTERO. 2004. Feeding preferences and food selection of the red swamp crayfish, Procambarus clarkii, in habitats differing in food item diversity. Crustaceana, 77: 435-453.

ALLIER, C. L., L. RAMÍREZ-DÍAZ \& F. GONZÁLEZ-BERNÁLDEZ. 1974. Doñana: Mapa Ecológico. Publicaciones del CSIC, Sevilla. 12 pp.

ALVÁREZ, S. E., M. C. GUERRERO \& C. MONTES. 2001. Descomposition of Juncus maritimus in two shallow lakes of Doñana National Park. Int. Rev. Hydrobiol., 86: 541-554.

ARAMBARRI P., F. CABRERA \& R. GONZÁLEZQUESADA. 1996. Quality evaluation of the waters entering the Doñana National Park (SW Spain). Sci. Total Environ., 191: 185-196.

ARAMBARRI, P., F. CABRERA \& C. G. TOCA. 1984. La contaminación del río Guadiamar y su zona de influencia, Marismas del Guadalquivir y Coto Doñana, por residuos de industrias mineras y agrícolas. Talleres Gráficos. CSIC. Madrid. 174 pp.

ARMENGOL, J. 1976 Crustáceos acuáticos del Coto de Doñana. Oecologia aquatica, 2: 93-97.

BERNUÉS, M., 1990. Limnología de los sistemas acuáticos del Parque Nacional de Doñana. Ph.D. Thesis. Universidad Autónoma de Madrid. 242 pp.

BIGOT, L. \& F. MARAZANOF. 1965. Considérations sur 1'écologie des invertébrés terrestres et aquatiques des Marismas du Guadalquivir. Vie et Milieu, 16: 411-473.

BRAVO, M. A. \& C. MONTES. 1993. Inventario de las formaciones palustres del manto eólico del Parque Nacional de Doñana (SW España). In: Actas VI Congreso Español de Limnología. L. Cruz, R. Morales, P. Sánchez, and P. Carrillo (eds.): 31-44. Facultad de Ciencias, Granada (Spain).

CABRERA, F., C. G. TOCA, E. DÍAZ \& P. ARAMBARRI. 1984. Acid mine-water and agricultural pollution in a river skirting the Doñana National Park (Guadiamar River, South West Spain). Water Research, 18: 1469-1482.

CABRERA, F., R. CORDÓN \& P. ARAMBARRI. 1987. Metales pesados en las aguas y sedimentos de los estuarios de los ríos Guadalquivir y Barbate. Limnetica, 3: 281-290. 
CLEMENTE, L., L. V. GARCÍA \& P. SILJESTRÖM. 1998. Suelos del Parque Nacional de Doñana. Ministerio de Medio Ambiente. Madrid (Spain). 205 pp.

CLEMENTE, L., L. VENTURA, J. L. ESPINAR, J. S. CARA \& A. MORENO. 2004. Las marismas del Parque Nacional de Doñana. Investigación y Ciencia, mayo 2004: 72-83.

CRUZ VILLALÓN, J. 2005. El desarrollo agrícola en el entorno de Doñana. Transformaciones territoriales y pasiajísticas. In: Doñana. Agua y Biosfera. F. García Novo \& C. Marín Cabrera (eds.): 263-267. Doñana 2005, Confederación Hidrográfica del Guadalquivir, Ministerio de Medio Ambiente, Madrid (Spain).

DE CASTRO-OCHOA, F. \& J. C. MUÑOZ-REINOSO. 1997. Model of long-term water-table dynamics at Doñana National Park. Water Research, 31: 2586-2596.

DE GROOT, C. J. \& H. L. GOLTERMAN. 1990. Sequential fractionation of sediment phoshate. Hydrobiologia, 192: 143-149.

DE RIDDER, M. 1962. Recherches sur les Rotifères des eaux saumâtres. VIII. Quelques Rotifères des Marismas espagnoles. Hidrobiologia, 20: 92-109.

DÍAZ-BARRADAS, M. C. \& J. C. MUÑOZ-REINOSO. 1992. The ecology of vegetation of the Asperillo dune system, southwest Spain. In: Coastal Dunes. Carter, Curtis \& SheehySkeffington (eds.): 211-218. Balkema, Rotterdam. The Netherlands.

DÍAZ-ESPEJO, A., L. SERRANO, \& J. TOJA. 1999. Changes in sediment phosphate composition of seasonal ponds during filling. Hydrobiologia, 392: 21-28.

DÍAZ-PANIAGUA, C. 1979. Estudio de las interacciones entre Triturus marmoratus y Triturus boscai (Amphibia: Caudata) durante su periodo larvario". Doñana Acta Vertebrata, 6: 19-53.

DÍAZ-PANIAGUA, C. 1988. Temporal segregation in larval amphibian communities in temporary ponds at a locality in SW Spain. Amphibia Reptilia, 9: 15-26.

DÍAZ-PANIAGUA, C. 1990. Temporary ponds as breeding sites of amphibians at a locality in Southwestern Spain. Herpetological Journal, 1: 447-453.

DÍAZ-PANIAGUA, C., GÓMEZ RODRÍGUEZ, C., PORTHEAULT, A. \& W. DE VRIES. In press. Los anfibios de Doñana. Ministerio de Agricultura. Organismo Autónomo de Parques Nacionales. Colección Técnica.
DOLZ, J. \& E. VELASCO. 1990. Análisis cualitativo de la hidrología superficial de las cuencas vertientes a la marisma del Parque Nacional de Doñana (Informe Técnico). Universidad Politécnica de Cataluña. 152 pp.

DUARTE, C., C. MONTES, S. AGUSTÍ, P. MARTINO, M. BERNUÉS \& J. KALFF. 1990. Biomasa de macrófitos acuáticos en la marisma del Parque Nacional de Doñana (SW España): importancia y factores ambientales que controlan su distribución. Limnetica, 6: 1-12.

DUSSART, B. H. 1964. Copépodes d'Espagne. Bull. Soc. Zool. Fr., 89 2/3: 117-125.

DUSSART, B.H. 1967. Contribution à l'étude des Copépodes d'Espagne. P. Inst. Biol. Apl., 42: 87105.

ESPINAR, J. L. 2000. Distribución espacial y temporal de las comunidades de macrófitos acuáticos de la "Marisma salada" del Parque Nacional de Doñana. Master Thesis. Universidad de Sevilla (Spain). 126 pp.

ESPINAR, J. L. 2004. Ecología de las comunidades de grandes helófitos de la marisma de Doñana. Ph. D. Thesis. Universidad de Sevilla (Spain). 214 pp.

ESPINAR, J. L., L. V. GARCÍA, P. GARCÍA-MURILLO \& J. TOJA. 2002. Submerged macrophyte zonation in a Mediterranean salt marsh: a facilitation effect from established helophytes? J. Veg. Sci., 13: 831-840.

ESTRADA, M. 1973. Nota sobre diaptòmids del Coto de Doñana. Treb. Soc. Cat. Biol., 32: 127134.

FAHD, K., L. SERRANO \& J. TOJA. 2000. Crustacean and rotifer composition of temporary ponds in the Doñana National Park (SW Spain) during floods. Hydrobiologia, 436: 41-99.

FERNÁNDEZ-DELGADO, C., P. DRAKE, A. M. ARIAS, \& D. GARCÍA-GONZÁLEZ. 2000. Peces de Doñana y su entorno. Ministerio de Medio Ambiente, Organismo Autónomo de Parques Nacionales. 272 pp.

FUREST, A. \& J. TOJA. 1981. Ecosistemas acuáticos del Parque Nacional de Doñana: Distribución del zooplancton. In: Actas del Primer Simposio sobre el Agua en Andalucía. Granada (Spain): 151-167.

GALINDO, M. D., N. MAZUELOS, A. J. MATA \& L. SERRANO. 1994a. Microcrustacean and rotifer diversity relating to water temporality in dune ponds of the Doñana National Park. Verh. Int. Verein. Limnol., 25: 1350-1356.

GALINDO, M. D., L. SERRANO, H. SEGERS, \& N. MAZUELOS. 1994b. Lecane donyanensis $\mathrm{n}$. 
sp. (Rotifera: Monogodonta, Lecanidae) from the Doñana National Park (Spain). Hydrobiologia, 284: 235-239.

GALLARDO, A. \& J. MERINO. 1993. Leaf decomposition in two Mediterranean ecosystems of Southwest Spain: influence of substrate quality. Ecology, 74: 152-161.

GALLEGO-FERNÁNDEZ, J. B. \& F. GARCÍANOVO. 2003. Bases ecológicas para la restauración de marismas de régimen mareal en el estuario del Guadalquivir. Rev. Soc. Gad. Hist. Nat., 3: 243-249.

GARCÍA MURILLO, P., M. BERNUÉS \& C. MONTES. 1993. Los macrófitos acuáticos del Parque Nacional de Doñana. Aspectos florísticos. In: Actas VI Congreso Español de Limnología. L. Cruz-Pizarro, R. Morales-Baquero, P. SánchezCastillo y P. Carrillo (eds.): 261-267. Facultad de Ciencias, Granada (Spain).

GARCÍA-NOVO, F., D. GALINDO, J. A. GARCÍA SÁNCHEZ, C. GUISANDE, J. JAUREGUI, T. LÓPEZ, N. MAZUELOS, J. C. MUÑOZ, L. SERRANO \& J. TOJA. 1991. Tipificación de los ecosistemas acuáticos sobre sustrato arenoso del Parque Nacional de Doñana. Actas del III Simposio del agua en Andalucía. Córdoba. Vol 1: 165-176.

GARCÍA-NOVO, F., M. ZUNZUNEGUI, J. C. MUÑOZ-REINOSO, J. B. GALLEGO-FERNÁNDEZ \& M. C. DÍAZ-BARRADAS. 1996. Surface and groundwater control on ecosystem development: the case of Doñana National Park (SW Spain). In: Wetlands: a multiapproach perspective J. Cruz-Sanjulián \& J. Benavente (eds.): 81-101. University of Granada, Granada (Spain).

GOLTERMAN, H. L. 1991. Direct nesslerization of ammonia and nitrate in fresh-water. Annls Limnol., 27: 99-101.

GONZÁLEZ QUESADA, R., F. CABRERA, E. DÍAZ \& P. ARAMBARRI. 1987. La calidad de las aguas del río Gaudiamar y de los arroyos de La Rocina y el Partido en las proximidades de Doñana. SW de España. Limnetica, 3: 97-102.

GRANADOS-CORONA, M., A. MARTÍN-VICENTE \& F. GARCÍA-NOVO. 1988. Long-term vegetation changes on the stabilized dunes of Doñana National Park (SW Spain). Vegetatio, 75: 73-80.

GRIMALT, J. O., I. YRUELA, C. SÁINZ-JIMÉNEZ, J. TOJA, J. W. LEEUW \& J. ALBAIGÉS. 1991. Sedimentary lipid biogeochemistry of and hypertrophic alkaline lagoon. Geoch. Cosmoch. Acta, 55: 2555-2577.
GUTIÉRREZ-YURRITA, P. J., G. SANCHO, M. A. BRAVO, A. BALTANÁS \& C. MONTES. 1998. Diet of the red swamp crayfish Procambarus clarkii in natural ecosystems of the Doñana National Park temporary freshwater marsh (Spain). $J$. Crustacean Biol., 18: 120-127.

I.N.I.A. 1984. Características de las aguas del Parque Nacional de Doñana en años de fuerte sequía. Publicaciones del I.N.I.A. Madrid (Spain). $197 \mathrm{pp}$.

I.T.G.E. 1993. Las aguas subterráneas en España. Estudio de síntesis. Instituto Tecnológico Geominero de España, Madrid (Spain). 591 pp.

JAUREGUI, J \& J. A. GARCÍA-SÁNCHEZ 1994. Fractionation of sedimentary phosphorus: a comparison of four methods. Verh. Int. Verein. Limnol., 25: 1150-1152.

JAUREGUI, J. \& J. TOJA. 1993. Dinámica del fósforo en lagunas temporales del P. N. de Doñana. In: Actas VI Congreso Español de Limnología. L. Cruz-Pizarro, R. Morales-Baquero, P. SánchezCastillo \& P. Carrillo (eds.): 99-106. Facultad de Ciencias, Granada (Spain).

JUNK, W. F. \& G. E. WEBER. 1996. Amazonian floodplains: a limnological perspective. Verh. Internat. Verein Limnol., 26: 149-158.

JUNTA DE ANDALUCÍA. 2002. Plan andaluz de humedales. Consejería de Medio Ambiente, Sevilla (Spain). 253 pp.

KONIKOW, L. F. \& J. RODRÍGUEZ ARÉVALO. 1993. Advection and diffusion in a variable-salinity confining layer: Water Resources Research, 29: 2747-2761.

LLAMAS, R. 1990. Geomorphology of the eolian sands of the Doñana National Park (Spain). Catena Supplement, 18: 145-154.

LÓPEZ, T., N. A. GABELLONE, J. JAÚREGUI \& J. TOJA. 1997. Paleolimnological studies at Santa Olalla and Dulce ponds in Doñana National Park. In: The Ecology and Conservation of European Dunes. F. García Novo, R.M.M. Crawford y M.C. Díaz Barradas (eds.): 229-236. Serv. Publ. Univ. Sevilla, Sevilla (Spain).

LÓPEZ, T., J. ROMÁN \& J. TOJA. 1993. Diatomeas de los sedimentos de las lagunas de santa Olalla y Dulce (P.N. Doñana). In: Actas VI Congreso Español de Limnología. L. Cruz-Pizarro, R. Morales-Baquero, P. Sánchez-Castillo \& P. Carrillo (eds.): 291-298. Facultad de Ciencias, Granada (Spain).

LÓPEZ, T., J. TOJA \& N. A. GABELLONE. 1991. Limnological comparison of two peridunar ponds 
in the Doñana National Park (Spain). Arch. Hydrobiol., 120: 357-378.

LÓPEZ, T., N. MAZUELOS \& J. C. MUÑOZ. 1994. Spatial and temporal variations in chemical characteristics of groundwater in the Biological Reserve of Doñana (SW, Spain). Verh. int. Verein. Limnol., 25: 1438-1444.

LÓPEZ-ARCHILA, A. I., S. MOLLÁ, M. C. COLETO, M. C. GUERRERO \& C. MONTES. 2004. Ecosystem metabolism in a Mediterranean shallow lake (Laguna de Santa Olalla, Doñana Nacional Park, Sw Spain). Wetlands, 24: 848-858.

LOZANO, E. 2004. Las aguas subterráneas en Los Cotos de Doñana y su influencia en las lagunas. $\mathrm{Ph}$. D. Thesis. Universidad Politécnica de Barcelona (Spain). 414 pp.

MANZANO, M. 2001. Clasificación de los humedales de Doñana atendiendo a su funcionamiento hidrológico. Hidrogeología y Recursos Hidráulicos, XXIV: 57-75.

MARAZANOF, F. 1967. Ostracodes, Cladocères, Hétéroptères et hydracariens noveaux pour les Marismas du Guadalquivir (Andalousie). Données écologiques. Annales de Limnologie, 3: 47-64.

MARGALEF, R. 1976. Algas de agua dulce de Doñana. Oecologia aquatica, 2: 79-93.

MARGALEF, R. 1983. Limnología. Ed. Omega, Barcelona (Spain). $1010 \mathrm{pp}$.

MARTÍ, E., J. AUMATELL, L. GODE, M. POCH \& F. SABATER. 2004. Nutrient retention efficiency in streams receiving inputs from wastewater treatment plants. J. Environ. Qual., 33: 285-293.

MAZUELOS, N., J. TOJA \& C. GUISANDE. 1993. Rotifers in ephemeral ponds of Doñana National Park. Hidrobiología, 255/256: 429-434.

MÉNANTEAU, L. 1982. Les Marismes du Guadalquivir, exemple de transformation d'un paysage alluvial au curs du Quaternaire recent. Ph. D. Thesis. Université Paris-Sorbone, Paris (France). $252 \mathrm{pp}$.

MiLlÁN, A., C. HERNANDO, P. AGUILERA, A. CASTRO \& I. RIBERA. 2005. Los coleópteros acuáticos y semiacuáticos de Doñana: reconocimiento de su biodiversidad y prioridades de conservación. Boletín de la SEA, 36: 157-164.

MINTEGUI, J. A. 1999. El futuro de las zonas húmedas. $1^{a}$ Reunión internacional de expertos sobre la regeneración hídrica de Doñana. Ministerio de Medio Ambiente, Madrid (Spain): 39-50.

MINTEGUI, J. A. 2005. El Arroyo del Partido. In: Doñana. Agua y Biosfera. F. García Novo \& C. Marín Cabrera (eds.): 151-154. Doñana 2005,
Confederación Hidrográfica del Guadalquivir, Minsterio de Medio Ambiente. Madrid (Spain).

MONTES, C. \& L. RAMÍREZ DÍAZ. 1982. Indicadores ecológicos de algunos ecosistemas acuáticos del Bajo Guadalquivir (SW España): odonatos, heterópteros y coleópteros acuáticos. In: Actas del I Congreso Español de Limnología. N. Prat (ed.): 43-49. Barcelona (Spain).

MONTES, C., J. AMAT \& L. RAMÍREZ-DÍAZ. 1982. Ecosistemas acuáticos del Bajo Guadalquivir (SW España). Variación estacional de los componentes físico-químicos y biológicos de las aguas. Studia Oecologica, 3: 159-180.

MUÑOZ-REINOSO J. C. \& F. GARCÍA-NOVO. 2005. Multiscale control of vegetation patterns: the case of Doñana (SW Spain). Landscape Ecology, 20: 51-61.

MUÑOZ-REINOSO, J. C. 1996. Tipología de las descargas sobre arenas de la Reserva Biológica de Doñana. Limnetica, 12: 53-63.

MUÑOZ-REINOSO, J. C. 2001. Vegetation changes and groundwater abstraction in SW Doñana, Spain. J. Hydrology, 242: 197-209.

MURPHY, J. \& J. P. RILEY. 1962. A modified single solution method for the determination of soluble phosphate in natural waters. Analit. Chem. Acta, 27: 31-36.

PÉREZ CABRERA, J. \& J. TOJA. 1986. Introducción al conocimiento de las comunidades de ciliados en la zona de la laguna de Santa Olalla (P.N. de Doñana). Oxyura, V: 5-29.

PLATA, J. L. \& F. M. RUÍZ SÁNCHEZ-AGUILILLA. 2003. Avance de los trabajos geofísicos últimamente realizados en el acuífero AlmonteMarismas (Doñana). In: Tecnología de la intrusión de agua de mar en acuiferos costeros: países mediterráneos. IGME, Madrid (Spain): 177-185.

PRAT, N., J. TOJA, C. SOLÁ, M. D. BURGOS, M. PLANS \& M. RIERADEVALL. 1999. Effect of dumping and cleaning activities on the aquatic ecosystem of the Guadiamar River following a toxic flood. Sci. Total Environ., 242: 231-248.

RAMOS, L., L. M. HERNÁNDEZ \& M. J. GONZÁLEZ. 1994. Sequential fractionation of Copper, Lead, Cadmium and Zinc in soils from or near Doñana National Park. J. Environ. Qual., 23: 50-57.

RODIER, J. 1981. Análisis de las aguas: aguas naturales, aguas residuales, aguas de mar. Ed. Omega, Barcelona (Spain). 1059 pp.

RUIZ, F., M. L. GONZÁLEZ REGALADO, L. SERRANO \& J. TOJA. 1996 Ostrácodos de las 
lagunas temporales del Parque Nacional de Doñana. Aestuaria, 4: 125-140.

SACKS, L. A, J. S. HERMAN, L. F. KONIKOW \& A. L. VELA. 1992. Seasonal dynamics of groundwater-lake interactions at Doñana National National Park, Spain. J. Hydrol., 136: 123-154.

SACKS, L. 1989. Seasonal dynamics of groundwater-lake interaction at Doñana National Park, Spain. Master Thesis. University of Virginia (USA). 173 pp.

SCHINDLER, D. W. 1971. Light, temperature and oxygen regimes of selected lakes in the Experimental Lake Area (ELA), northwestern Ontario. J. Fish. Res. Bd. Can., 28: 157-169.

SERRANO, L. \& L. SERRANO. 1996. Influence of groundwater exploitation for urban water supply on temporary ponds from the Doñana National Park (SW Spain). J. Environmental Management, 46: 229-238.

SERRANO, L., M. REINA, A. ARECHEDERRA M. A. CASCO \& J. TOJA. 2004. Limnological description of the Tarelo lagoon (SW Spain). Limnetica, 23: 1-10.

SERRANO, L., M. REINA, E. DE VERD, J. TOJA \& H. L. GOLTERMAN. 2000a. Determination of the sediment phosphate composition by EDTA meted of fractionation. Limnetica, 19: 199-204.

SERRANO L., R. M. LAMELAS, J. JAUREGUI \& J. TOJA. 1994. Daily variations in two ponds of different mixing dynamics in the Doñana N. P. (SW, Spain). Verh. Int.. Verein Limnol., 25: 13451349.

SERRANO, L. \& C. GUISANDE. 1990. Effects of phenolic compounds on phytoplankton. Verh. int. Verein. Limnol., 24: 282-288.

SERRANO, L. \& J. TOJA. 1995. Limnological description of four temporary ponds in the Doñana National Park (SW, Spain). Arch. Hydrobiol., 133: 497-516.

SERRANO, L. \& J. TOJA. 1998 Interannual variability in the zooplankton community of shallow temporary pond. Verh. Internat. Verein Limnol., 26: $1575-1581$.

SERRANO, L. \& K. FAHD. 2005. Zooplankton communities across a hydroperiod gradient of temporary ponds in the Doñana National Park (SW Spain). Wetlands, 25: 101-111.

SERRANO, L. 1992. Leaching from vegetation of soluble polyphenolic compounds, and their abundance in temporary ponds in the Doñana National Park (SW, Spain). Hidrobiologia, 229: 43-50.
SERRANO, L., R. SEMPERE, L. TORRES \& J. TOJA. 1993. Efecto de compuestos polifenólicos naturales sobre el crecimiento de Chlamydomonas $s p$. en lagunas del P.N. de Doñana. In: Actas VI Congreso Español de Limnología. L. CruzPizarro, R. Morales-Baquero, P. Sánchez-Castillo \& P. Carrillo (eds.): 245-252. Facultad de Ciencias, Granada (Spain).

SERRANO, L., I. CALZADA-BUJAK \& J. TOJA. 2003. Variability of the sediment phosphate composition of a temporary pond (Doñana National Park, SW Spain). Hydrobiologia, 429: 159-169.

SERRANO, L., M. D. BURGOS, A. DÍAZ-ESPEJO \& J. TOJA. 1999. Phosphorus inputs to wetlands following storm events after drought. Wetlands, 19: 318-326.

SERRANO, L., P. PÉREZ-ROMERO, A. PLAZUELO, A. TORRES \& J. TOJA. 2000b. Microbial degradation of dissolved polyphenolic compounds in sesonal- ponds. Verh. int. Verein. Limnol., 27: 3252-3259.

SERRANO, L. 1994. Sources, abundance and disappearance of polyphenolic compounds in temporary ponds of Doñana National Park (South-western Spain). Aus. J. Mar. Fresh. Res., 45: 1555-1564.

SILJESTRÖM, P. A. \& L. CLEMENTE. 1990. Geomorphology and soil evolution of a moving dune system in south-west Spain (Doñana National Park). J. Arid Environments, 18: 139-150.

SOUSA, A. \& P. GARCÍA-MURILLO. 1999. Historical evolution of the Abalario lagoon complexes (Doñana Natural Park, SW Spain). Limnetica, 16: 85-98.

SOUSA, A. \& P. GARCÍA-MURILLO. 2003. Changes in the wetlands of Andalusia (Doñana Natural Park, SW Spain) at the end of the Little Ice Age. Climatic Change, 58: 193-217.

TOJA, J., T. LÓPEZ \& N. GABELLONE. 1991. Succesional changes in two dune ponds (Doñana National Park). Verh. int. Verein. Limnol., 24: 1556-1559.

TOJA, J., T. LÓPEZ \& N. A. GABELLONE. 1997. Limnology of the permanent dune ponds in Doñana National Park. In: The Ecology and Conservation of European Dunes. F. García-Novo, R. M. M. Crawford \& M. C. Díaz-Barradas (eds.): 221-228. Serv. Publ. Univ. Sevilla, Sevilla (Spain).

VANNEY, J. R. \& L. MENANTEAU, 1985. Physiographic map of the Atlantic litoral of Andalousia 1/50 000. Junta de Andalucía. 
VELA, A. 1984. Estudio preliminar de la hidrogeología e hidrogeoquímica del sistema de dunas móviles y flecha litoral del Parque Nacional de Doñana. Master Thesis. Universidad Complutense de Madrid. $221 \mathrm{pp}$.

WILLIAMS, P., J. BIGGS, G. FOX, N. PASCALE, \& M. WHITFIELD. 2001. History, origins and importance of temporary ponds. Freshwater Forum, 17: 7-15.

ZUNZUNEGUI, M., M. C. DÍAZ-BARRADAS \& F. GARCÍA-NOVO. 1998. Vegetation fluctuation in
Mediterranean dune ponds in relation to rainfall variation and water extraction. Appl. Veg. Sci., 1: 151-160.

ZURERA COSANO, G., F. RINCÓN LEÓN, L. M. POLO VILLAR, M. JODRAL VILLAREJO, R. JORDANO SALINAS \& R. POZO LORA. 1987. Contaminación por plomo, cadmio y mercurio en aguas y sedimentos del río Guadalquivir. In: Actas del IV Congreso Español de Limnología. Sevilla (Spain): 307-314. 